Bianca Burke, Adrian Slee, Peter D. McIntosh, Harald Hofmann, and James Shulmeister. A reactivated cave system induces rapidly developing cover-collapse sinkholes in Tasmania, Australia. Journal of Cave and Karst Studies, v. 82, no. 1, p. 31-50. DOI:10.4311/2019ES0109

\title{
A REACTIVATED CAVE SYSTEM INDUCES RAPIDLY DEVELOPING COVER-COLLAPSE SINKHOLES IN TASMANIA, AUSTRALIA
}

\author{
Bianca Burke ${ }^{1}$, Adrian Slee ${ }^{2}$, Peter D. McIntosh ${ }^{2, C}$, Harald Hofmann ${ }^{1}$, and James Shulmeister ${ }^{1}$
}

\begin{abstract}
The reasons of rapid development of cover-collapse sinkholes near Railton, Tasmania were investigated after sinkholes first appeared in a mature pine plantation in 2011. Sinkhole monitoring, dye tracing, chemical analyses of stream water and field observations indicated that large sinkholes in Quaternary alluvium overlying Ordovician limestone resulted from deepening of a limestone quarry south of the plantation. Intersection of a cave system during quarrying lowered the local water table, initiated streamsinks, and caused streams that previously flowed north towards the Mersey River to flow south to the quarry, via streamsinks and reactivated subsurface channels. Concurrently, the thickness of the vadose zone in thick Quaternary sediments overlying the limestone increased, hydraulic support for the sediments decreased, and numerous cover-collapse sinkholes formed. Chemical data including isotope analyses confirmed that the local aquifer is mainly recharged after high winter rainfall during high stream flow, when a proportion of the water in surface streams also flows directly northwards to the Mersey River. During low (summer) flow most water in surface streams flows into streamsinks and south into the quarry via the cave system. It is then pumped to a surface stream running north through the area in question, returns into the cave system via streamsinks and sinkholes, and finally returns to the quarry. The study demonstrates that water-table lowering by quarrying in limestone is not confined to cones of depression but may extend for kilometres if relict subsurface stream channels are intersected. In this area, the rapid development of cover-collapse sinkholes presents risks to infrastructure (a railway line, an electricity transmission line, and roads); to stream biodiversity because of altered water flow duration and water quality; to the safety of forest contractors, particularly those using heavy machines; and to the future use of presently productive land for economic return.
\end{abstract}

\section{Introduction}

The hazards associated with karst landforms are widely recognized (Langer, 2001; Bonacci, 2004; Cooper et al., 2011; Gutiérrez et al., 2014; Parise, 2015; Siska et al., 2016). The chief hazard evoked by karst processes is collapse of sinkholes, generally a natural process that occurs as a result of loss of surface strength by the enlargement of karst voids. Collapse sinkholes can be subdivided into those associated with cave roof collapse and those associated with collapse of thick overburden deposits mantling karst; the latter are called cover-collapse sinkholes (Kiernan, 2002; Gutiérrez et al., 2014).

Both sinkhole types develop by subsurface processes. Consequently, collapse can be difficult to predict. Before surface collapse occurs, karst voids in limestone bedrock may enlarge and cause erosion of sediment from the base of overlying overburden deposits, so that voids gradually extend towards the surface (Augarde et al., 2003; Kaufmann and Romanov, 2016; Jia et al., 2018). Eventually a void may become so big that the roof of the void cannot support itself and the ground surface suddenly collapses into a vertical or steep-walled sinkhole (Cooley, 2002). Overburden composed of layers of varying mechanical strength is particularly susceptible to collapse (Al-Halbouni et al., 2018). Laboratory simulations of this process have been detailed by Soliman et al. (2018). Once a collapse sinkhole has formed, continued vertical or horizontal development depends on the capacity of the underlying karstic voids to remove the collapsed material by suffusion. If the underlying voids are small, debris may block the karst cavities and sinkhole development may slow. However, if the voids are large and connected and the cover material is clay-rich and mobile, the sinkhole will continue to develop, particularly during high rainfall: suffusion processes will initially act on the collapsed material and later on the walls of the sinkhole, leading to sinkhole enlargement, so that over time the cover-collapse sinkhole changes from a vertical-sided hole to a cone (Calligaris et al. 2017; Lipar et al., 2019).

A notable example of a bedrock-collapse sinkhole was one which consumed a number of cars in a car museum in Kentucky, USA (Polk et al., 2015). Unbeknownst to the museum, its showroom was built on top of a large cave developed in limestone. By natural processes the roof of this cave had become almost too thin to support its weight and the added weight of the cars initiated its collapse. Although final collapse may be catastrophic, such roof-collapse sinkholes generally develop slowly, an example being the development of sinkholes overlying caves in the Stockyard Gully karst of Western Australia (Lipar et al., 2019). In contrast, cover-collapse sinkholes can develop rapidly and may not overlie a

\footnotetext{
${ }_{1}^{1}$ School of Earth and Environmental Sciences, University of Queensland, St Lucia 4072, QLD, Australia

2 Forest Practices Authority, 30 Patrick Street, Hobart 7000, TAS, Australia

c Corresponding Author: peter.mcintosh@fpa.tas.gov.au
} 
large cave. They may form during floods (Zhou and Lei, 2018) during which water flow and transport capacity in karstic voids may reach a maximum, or after groundwater extraction (Heidari et al., 2011; Khanlari et al., 2012). Water under pressure may liquify clay in overburden deposits above the karst contact, thereby undercutting the ground surface until roof failure occurs (Jia et al., 2018; Soliman et al. 2018). Examples of cover-collapse sinkholes forming rapidly after heavy rain have been documented in Europe (Gutiérrez-Santolalla, 2005; Martinotti et al., 2017; Noury et al., 2018; Parise et al., 2018), the US (Hyatt and Jacobs, 1996; Hunt et al., 2013), and in the Mole Creek karst of northern Tasmania (Slee et al., 2019).

There are also numerous documented examples of anthropogenic impacts triggering rapid development of cover-collapse sinkholes. A notable example is that presented by the draining of Victory Lake in Georgia (Jovanelly, 2014). This man-made recreational lake was entirely drained by the lowering of the groundwater table by limestone quarrying: as a result cover-collapse sinkholes formed beneath the lake bed and linked the water in the lake to an existing subsurface karst aquifer, which itself was connected to the quarry, causing the lake to drain overnight (Jovanelly, 2014). Similar aquifer drawdown impacts resulting from quarry and mine operations and aquifer over-exploitation have been described in Italy (Parise and Pascali, 2003; Dell'Aringa et al., 2014), China (Jia et al., 2018; Pan et al., 2018), Iran (Heidari et al., 2011; Khanlari et al., 2012) and Belgium (Kaufmann and Quinif, 2002), amongst numerous other examples of this phenomenon in the USA and elsewhere, as reviewed by Langer (2001, p. 15-30). If sinkholes and quarries are legally or illegally used to dispose of waste, then contamination of water supplies can occur (Delle Rose et al., 2007).

Globally, karst hazards have come under most scrutiny in urban or peri-urban environments close to housing or major infrastructure, where hazards like cover-collapse sinkholes pose substantial risk to structures and lives of residents, workers or travellers (Brinkmann et al., 2008). Careful planning can reduce risks, an example being the planning for urban expansion onto karst in the northern suburbs of Perth, Western Australia (Csaky, 2003), but, in general, laws and policy documents do not take into account the complexity and peculiarity of karst environments (LaMoreaux et al., 1997; Delle Rose et al., 2007).

Karst hazards in production forests generally receive less attention than those in urban or peri-urban areas. In Tasmania, karst underlain chiefly by Palaeozoic limestone and Proterozoic dolomite is extensive in forested terrain (Kiernan, 1989, 1995a, b) and commercial operations in these forests have the potential to affect karst values both by direct effects, such as physical damage to caves, and indirect effects, such as modification of surface and subsurface water quality and flow, which may affect stream biodiversity. Consequently, mapping of karst and the identification of potential hazards associated with forest operations have been important components of Tasmanian forest management since the 1980s (e.g., Jones et al., 1988; Eberhard, 1994, 1998; Kiernan, 1995a; Sharples, 2002). Prescriptions governing karst management were included in the Tasmania's first Forest Practices Code (Forest Practices Authority, 1987), since updated (Forest Practices Authority, 2015), which defines acceptable forest practices for the timber industry in the state.

Until 2011, it was considered that areas of active karst in Tasmania were well-known, the most obviously active areas being the Florentine and Tyenna valleys in the state's south and the Mole Creek area in the mid-northwest. In both these areas, maps of karst features have been prepared, many caves have been explored, and subsurface water flows monitored (Kiernan, 1995a, b; Eberhard, 1998). Other limestone or dolomite areas have received less attention. Relevant to the study described in this paper is that in 1961 karst pinnacles up to $30 \mathrm{~m}$ high overlain by Quaternary sediments were noted in the now disused Goliath quarry at Railton (Jennings, 1961) and in the 1970s and 1980s several karst sinkholes were documented in the Railton area (Matthews et al., 1983; Donaldson, 1984; Kiernan, 1995b, p. 181) and were related to water table lowering at the same quarry (Kiernan, 1995b, p. 182). In 2003, the Forest Practices Authority reported on cover-collapse sinkholes near the railway line north of Railton (N. Duhig, unpublished FPA report). Despite these signs of instability the Railton area was not considered to be susceptible to widespread karst development (Kiernan, 1995b; Eberhard, 2007) and a report investigating an alternative site for a proposed limestone quarry at Mt Cripps in northwest Tasmania (Grimes 1999) suggested quarrying at Railton would be environmentally less sensitive.

Recently, however, rapid development of large sinkholes in a Pinus radiata plantation north of Railton (Fig 1) has become a significant land management issue. In January 2011, a cover-collapse sinkhole $20 \mathrm{~m}$ diameter was noted in the southwest of the unharvested forest block, and by August 2011 it had expanded considerably. At this time, the sinkhole was considered to be an isolated occurrence and standard precautionary measures were applied: specifically, a no-machinery buffer zone around the sinkhole and re-location of a planned wood processing site (landing) from the vicinity of the sinkhole to elsewhere in the forest block. However, since harvest in 2012, many more sinkholes formed and it became clear that a comprehensive survey was required to assess risks and determine the causes of land instability.

This study was undertaken to record the evolution of the active karst landscape in the Railton Valley since 2011, relate sinkhole formation to surface and sub-surface flows, and attempt to identify why sinkholes have formed rapidly in a previously stable landscape. 


\section{Regional and Local Setting}

The Railton Valley lies in the central north of Tasmania (Fig. 1) $\left(41.31^{\circ} \mathrm{S}, 146.40^{\circ} \mathrm{E}\right)$. The valley is aligned approximately north-south and is a flat-floored depression about $20 \mathrm{~km}$ long and 3-6 km wide. The floor of the valley varies from $70 \mathrm{~m}$ above sea level (asl) in the south to $5 \mathrm{~m}$ asl in the north. The town of Railton lies in the southern part of the valley at an altitude of $65 \mathrm{~m}$ asl and the town of Latrobe and the Mersey River estuary lie at the north end of the valley. Immediately north of Railton is the Dulverton Pit (limestone quarry) and cement works operated by Cement Australia Pty Ltd (see Fig. 1).

The geology of the area was described by Jennings (1960) and McClenaghan (2003). The extensive Quaternary valley floor deposits are predominantly gravelly clays, assumed to have accumulated during the last glacial period or earlier when colluvial and alluvial processes were more active than at present (McIntosh et al., 2012). These sediments overlie a syncline with a north-south axis formed within Ordovician rocks, consisting of Gordon Group limestone overlying Moina Sandstone and Owen Conglomerate (which together form the Owen Group). The Badger Range (up to $548 \mathrm{~m}$ asl) west and south of the valley is formed by the resistant Owen Conglomerate. Bonneys Tier (up to $460 \mathrm{~m}$ asl) west and north of the valley consists of a Jurassic dolerite sill overlying subhorizontal Permian sedimentary rocks. The Dulverton hills (172 $\mathrm{m}$ asl) east of the valley are formed in Moina Sandstone. Because of lack of exposure, the Gordon

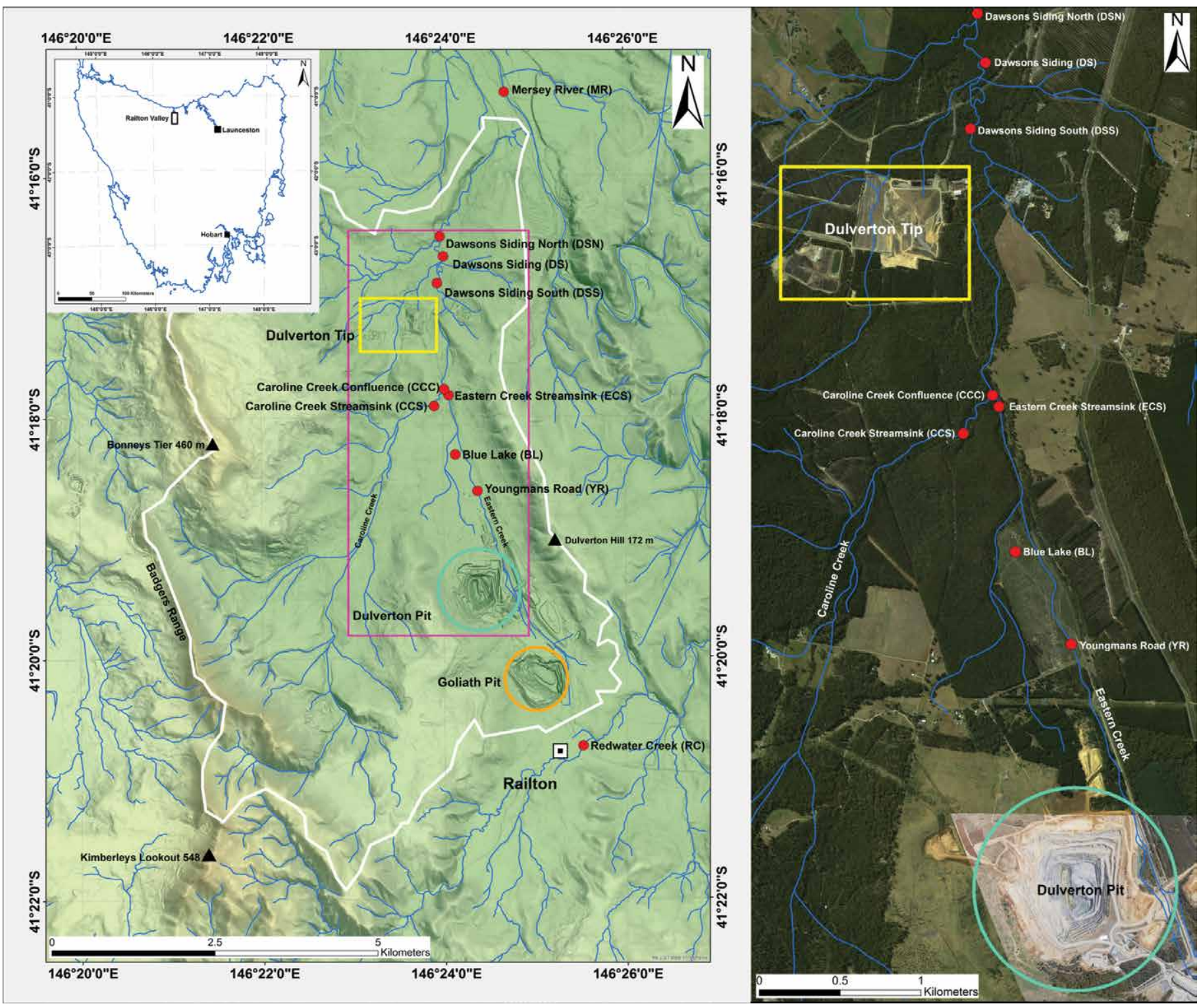

Figure 1. Left. General location map showing the Railton valley and the main topographic and drainage features of the study area. The locations indicated by red dots are karst sites at which experiments were conducted. The area of intensive study is outlined in pink. Right. Detail of intensive study area, showing sites at which experiments were conducted. 
Group limestone has not been subdivided and mapped in the detail possible in other areas, where three formations have been identified (Brown et al., 1982). The limestone is up to $1000 \mathrm{~m}$ thick and contains about $88 \% \mathrm{CaCO}_{3}$ and $5 \% \mathrm{SiO}_{2}$ (Jennings, 1960). The limestone contact with overlying Quaternary deposits is highly irregular and in places consists of near-vertical limestone pinnacles $30 \mathrm{~m}$ high; in addition, gravelly cave fillings were observed in early quarries (Jennings, 1959, 1961). The deep relict karst features in the phreatic zone are likely to have been created during periods of lower sea level, as noted by Grimes (1994) for deep caves of South Australia. On the basis of the limestone's thickness, areal extent, and lack of lateral confinement along the syncline axis, the Railton karst is classified as 'deepfree flowing karst' (Grimes, 1999).

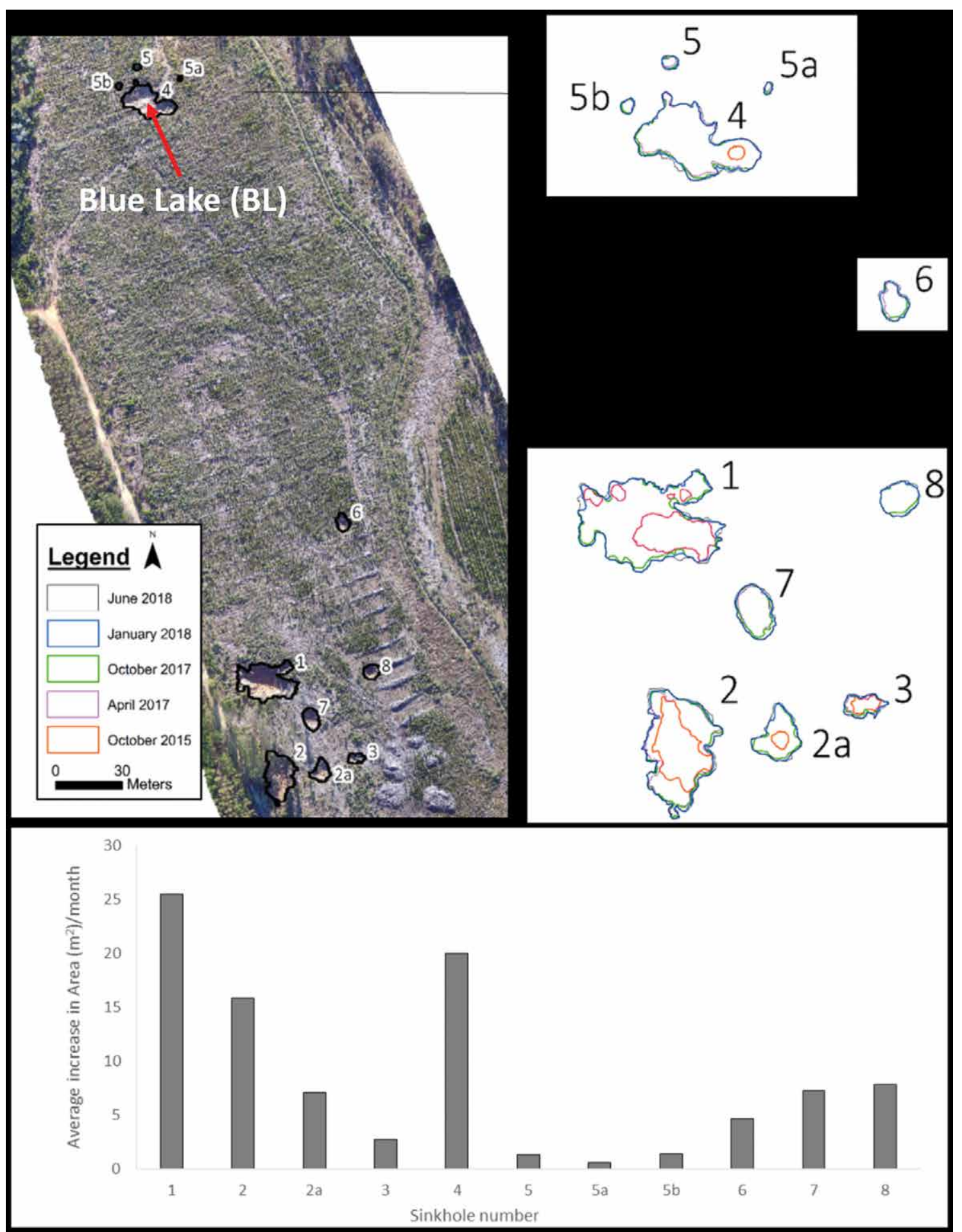

Figure 2. Sinkhole locations and development, October 2015 to June 2018. Blue Lake (Fig. 1) is arrowed for reference.
The southern end of the valley is drained by Redwater Creek that flows through the town of Railton and eastwards to the Mersey River (Fig. 1). The northern end of the valley and the plantation area is drained by Caroline Creek that has headwaters in the southwest of the valley. An unnamed stream running northwards from the limestone quarry (Dulverton Pit) on the eastern boundary of the plantation area that is the focus of this study is informally named Eastern Creek. It is largely a man-made channel and carries the drainage pumped from Dulverton Pit north to Caroline Creek. It is fabric-lined from Dulverton Pit to Youngmans Road (Fig. 1). Caroline Creek and its tributary Eastern Creek (Fig. 1) flow north to the Mersey River, which reaches the sea at Devonport, $25 \mathrm{~km}$ north of Railton.

Mean annual precipitation at Railton (Dowbiggin 
$\mathrm{St}$ ) is $1058 \mathrm{~mm}$ with a winter monthly maximum of $145 \mathrm{~mm}$ in July and a summer monthly minimum of $60 \mathrm{~mm}$ in January (Bureau of Meteorology, 2019). The mean monthly maximum and minimum temperatures at Sheffield, $9 \mathrm{~km}$ southwest of Railton are $22^{\circ} \mathrm{C}$ and $11^{\circ} \mathrm{C}$ in January and $12^{\circ} \mathrm{C}$ and $4{ }^{\circ} \mathrm{C}$ in June (Bureau of Meteorology 2019).

The valley has varied land use, including extensive areas of Eucalyptus nitens and Pinus radiata plantations managed by Forico Ltd., patches of native forest, small hobby farms primarily used for grazing, and limestone quarrying. Five kilometres north of Railton lies the Dulverton Tip, a major commercial waste solids and liquids disposal dump for northern Tasmania (Fig. 1).

\section{Methods}

To investigate the karst, we used combinations of field mapping, remote sensing, and hydrological and hydro-geochemical techniques. The project started in 2011 with observations and monitoring of sinkhole development. More intensive field mapping and hydrogeological investigations were carried out in 2017 and 2018.

\section{Mapping And Monitoring}

Documentation of the sinkholes and streamsinks present in the plantations north of Youngmans Road to began in early 2011. The first sinkhole documented (sinkhole 2, Fig. 2) was located in an unharvested Pinus radiata stand in 2011 and was mapped using a handheld GPS and a Leica Disto laser and compass. Between 2012 and 2014 development of sinkholes (including streamsinks) was monitored using a hand-held GPS and interpretation of photographic images (Fig. 2). In five surveys (in July 2015, October 2015, April 2017, October 2017 and January 2018) Forico Ltd employees mapped sinkhole extent using digital elevation models derived from high resolution imagery obtained from a DJ Phantom 4 drone equipped with a DJI FC330 camera. Each survey took on average 244 images with an average pixel size of $4.5 \mathrm{~cm}$. Digital elevation models (DEMs) were extracted using the 'Maps Made Easy' software for each of the 2017 and 2018 surveys and resampled at $0.5 \mathrm{~m}, 1 \mathrm{~m}$, and $3 \mathrm{~m}$ pixel sizes. Elevation data was not available for the 2015 survey. These images were supplemented by Google Earth Pro Imagery and the LiDar-derived shade maps of the area available on line at the List Tasmania website (www.thelist.com). Remote mapping was supplemented with field survey and ground-based photographs.

The semi-automated difference raster approach for defining sinkholes described by Doctor and Young (2013) was applied to ensure all sinkholes were identified, based on the assumption that depth values greater than $0.25 \mathrm{~m}$ were likely to indicate the presence of a sinkhole. Sinkhole boundaries were mapped in ArcMap v.10.5.10 by manual digitisation methods, aided by boundary enhancement using slope and curvature datasets. The evolution of sinkhole boundaries over $0.5,1,2$, and 5 years was determined using Excel. For most sinkholes the exact date of initial collapse and significant enlargement was unable to be recorded, as neither foresters nor researchers were based close to the study site.

Although groundwater monitoring has been conducted in the area, the information is privately held and results were not available to the research team.

\section{Stream Flow Measurements}

Flow measurements in the two main streams (Caroline Creek and Eastern Creek) draining the northern end of the Railton Valley were recorded over a period of 6 months. Herron dipperlog NANO water pressure sensors (Heron Inc.) were positioned on stakes approximately $10 \mathrm{~cm}$ above the bottom of stream channels to measure water depths. The sensors were located at three sites on Caroline Creek: upstream of the main streamsink (CCS); at Eastern Creek upstream of its streamsinks (YR); and on the lower Caroline Creek at Dawsons Siding South (DSS) (Fig. 2). At these sites Hobo temperature loggers were also attached to the stakes to measure water temperature at half-hour intervals. Herron air pressure sensors were installed nearby so that water pressure measurements could be compensated for atmospheric pressure variation. At three logger locations (CCS, CCC and YR; Fig. 2) the channel cross sectional area was measured using the sag-tape surveying technique (Ray and Megahan, 1979) involving measuring channel depth from an established benchmark (bank-full height) at $20 \mathrm{~cm}$ intervals along a transect to calculate the cross-sectional area. We were unable to measure actual stream flow at different stream levels to produce a rating curve. Therefore, we applied the Manning equation (Marcus et al., 1992) to approximate flow rates at different stream levels. The calculated rates were verified using a digital flow meter (Hydro-Bios Digital Flow Meter) and by measuring the speed of a floating orange during site visits.

Autogenic recharge from point sources was determined from differential flow gauging similar to the method described by Scanlon et al. (2002), involving determining the difference in flow upstream and downstream of the recharge zone. Flow upstream was measured upstream of Eastern Creek Streamsink (ECS) and upstream of Caroline Creek Streamsink (CCS). Flow downstream was measured at Caroline Creek downstream of the Confluence (CCC) (Fig. 2). Autogenic recharge from point sources was determined using:

$$
Q_{\text {auto }}=Q_{C C C}-\left(Q_{E C S}+Q_{C C S}\right)
$$


where $Q$ is discharge $\left[\mathrm{L} / \mathrm{T}^{3}\right]$ and subscripts indicate sources as explained in the text above. Rainfall data were obtained for the station at Dowbiggin St, Railton, $4.55 \mathrm{~km}$ south of the study area (Bureau of Meteorology, 2019).

\section{Dye-Tracing Experiments}

Dye-tracing experiments are common practice in karst areas to trace groundwater flow through karst and to investigate the connections between sinkholes, streams, and groundwater or subsurface channels (Lauber et al., 2014; Frisbee et al., 2019). Within Tasmania dye-tracing experiments have been used primarily to prove connections between inaccessible reaches of cave systems, for example at Exit Cave (Kiernan, 1993; Osborne 1994) and Mole Creek (Kiernan, 1989, 1990; Kiernan et al., 1994) and in the Florentine Valley (Eberhard, 1998; Sharples, 2018). However, elsewhere dye tracing has been used in a broader range of karst and non-karst groundwater studies including the tracing of vadose zone karst water dispersal (Poulain et al., 2018) and the tracing of water drainage through sub-glacial meltwater channels (Flett et al., 2017; Miles et al., 2019).

Streamsinks were located early in this study, but no accessible caves were found and flow directions within the underlying karst were unknown. For this reason, four dye tracing experiments (Table 1) were undertaken to identify flow pathways during low and high stream flows. The first experiment was conducted in July 2017 (winter). The second was in January 2018 (summer). The third and fourth were conducted in July 2018 (winter). Experiments 3 and 4 included assessments of flow velocities.

Cumulative dye concentrations measured in charcoal bags retrieved from sampling sites (Fig. 1) were normalized (NC-ppb) by dye injection concentrations so that direct comparisons between dye-tracing experiments could be made. Normalized cumulative values were determined by dividing the received dye concentrations by the input dye concentration, to allow received concentration values to be directly compared between experiments (Goldscheider et al., 2008). For all four experiments (Table 1) activated charcoal bags were sampled at each site before dye injection to detect any background dye pollution in the water.

The aim of Experiment 1 was to determine whether water flowing into Caroline Creek Streamsink (CCS) at low flow flowed north (to the lower reaches of Caroline Creek) or south (to the upper reach of Eastern Creek). The aim of Experiment 2 was to determine whether water flowing into Eastern Creek Streamsinks (ECS) at low flow flowed north (to the lower reaches of Caroline Creek or the Mersey River) or south (to the upper reach of Eastern Creek or Redwater Creek). The aim of Experiment 3 was to determine whether water flowing into Blue Lake (BL) at high flow flowed north (to the lower reaches of Caroline Creek) or south (to the upper reach of Eastern Creek or Redwater Creek). The aim of Experiment 4 was to determine whether water flowing into Caroline Creek Streamsink (CCS) at high flow flowed north (to the lower reaches of Caroline Creek) or south (to the upper reach of Eastern Creek or Redwater Creek) and to establish flow rates by accurate timing of dye arrival using a fluorimeter.

Fluorescein (green) and Rhodamine WT (red) were used as tracing dyes. Dye-tracing experiments used activated charcoal bags installed and removed from streams to establish subsurface flow pathways. After their removal from streams, bags were sent to Ozark Underground Laboratory, USA for dye analysis. For the third and fourth experiments, two Turner Cyclops C7 Fluorimeters were set up in Eastern Creek near Youngmans Road (YR) and at Caroline Creek at Dawsons Siding North (DSN). Charcoal bags were also used. The loggers were set up to record fluorescence at 1-min intervals over $178 \mathrm{~h}(7.5$ days) beginning on July 27,2018 . Unfortunately, although the fluorimeter at DSN returned a complete dataset, the YR instrument malfunctioned.

\section{Water Chemistry}

Water was sampled for major ion chemistry and stable isotope analysis to supplement the dye-tracing experiments. The first water sampling was during low flow and was undertaken on January 16, 2018. Three days before water sample collection $8 \mathrm{~mm}$ of rainfall was recorded and no rainfall occurred during sampling. Sampling was undertaken at YR, DS, RC and MR (Fig. 1). Water was collected from streams in rinsed $250 \mathrm{~mL}$ bottles for

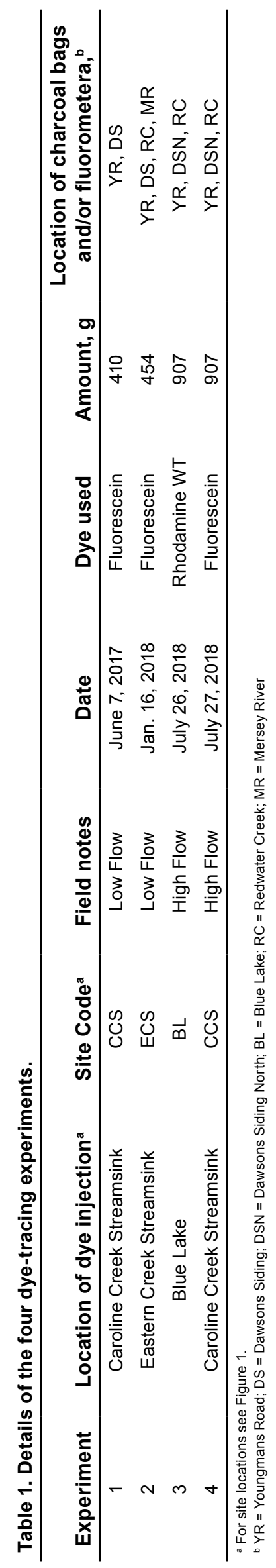


major ions and $125 \mathrm{~mL}$ bottles for stable isotopes, ensuring no air was trapped in the bottles. Samples for major ion analysis were filtered with $0.45 \mu \mathrm{m}$ filters and stored at $\sim 2{ }^{\circ} \mathrm{C}$ before being analysed. In situ measurements for electrical conductivity (EC), dissolved oxygen (DO), $\mathrm{pH}$ and temperature $\left({ }^{\circ} \mathrm{C}\right)$ were taken concurrently using ProDSS water-parameter water quality meters. Stable isotope values $\left(\delta^{2} \mathrm{H}\right.$ and $\left.\delta^{18} \mathrm{O}\right)$ in rainfall were approximated from the Global Network of Isotopes in Precipitation (GNIP) archives for Cape Grim, Tasmania (GNIP 2018). The second water sampling was during high flow and was undertaken on January 25, 2018 at YR and DSN, on January 26 at CCS and ECS and on January 29 at five northern streams (not shown in Fig. 1). $29.4 \mathrm{~mm}$ of rain fell on January 24, 2018, $18.2 \mathrm{~mm}$ on January 25, 2018, no rain fell January 26-28, 2018 and $19 \mathrm{~mm}$ fell on January 29, 2018.

Chemical analyses followed the methods of Baublys et al. (2015) and Filippini et al. (2018) and were conducted at the School of Earth and Environmental Sciences at the University of Queensland. Major anions were measured by ion chromatography (IC) using a Dionx ICS 1100 instrument. Samples for major cation analysis were acidified with $70 \%$ $\mathrm{HNO}_{3}$ and cations were measured using ICP OES (Inductively Coupled Plasma Optical Emission Spectrometry). The precision for major ion concentrations was calculated from replicate samples and was $\pm 2 \%$. Bicarbonate $\left(\mathrm{HCO}_{3}{ }^{-}\right)$and carbon dioxide $\left(\mathrm{CO}_{2}\right)$ concentrations were determined by $\mathrm{pH}$ titration both in the field and in the laboratory, within 7 days of sample collection. A Hatch Digital Titrator with an accuracy of $\pm 1 \%$ was used. Titration results expressed in $\mathrm{HCO}_{3}$ of $\mathrm{CaCO}_{3}$ were converted to $\mathrm{HCO}_{3}{ }^{-}$concentrations using the stoichiometric multiplication factor of 1.22.

Water-stable isotopes of $\delta^{18} \mathrm{O}$ and $\delta^{2} \mathrm{H}$ were analysed in the stable isotope laboratory at the University of Queensland (UQ-SIGL) following methods used by Baublys et al. (2015). An Isoprime dual inlet isotope mass spectrometer was used with an accuracy of \pm 0.08 per $\mathrm{mL}$ for ${ }^{18} \mathrm{O}$ and \pm 1.0 per $\mathrm{mL}$ for ${ }^{2} \mathrm{H}$. $\delta^{2} \mathrm{H}$ values were analysed after online equilibration at $40{ }^{\circ} \mathrm{C}$ with Hokko coils. $\delta^{18} \mathrm{O}$ values were analysed after equilibration with carbon dioxide. $\delta^{2} \mathrm{H}$ and $\delta^{18} \mathrm{O}$ values in VSMOW \%o were normalized to standard mean ocean water (VSMOW-SLAP), following a 3-point normalization based on replicate analyses with international standards USGS45 and USGS46. All laboratory standards were calibrated against IAEA (VSMOW, SLAP, GISP). Accuracy and precision were better than $\pm 1 \%$ for $\delta^{2} \mathrm{H}$ and $\pm 0.05 \%$ for $\delta^{18} \mathrm{O}$ at 10. $\delta^{13} \mathrm{C}$-DIC was analysed by a Thermo Delta $V$ continuous-flow isotope ratio mass spectrometer (CF-IRMS) coupled to a Gas Bench II. $\delta^{13} \mathrm{C}$-DIC values were normalized to the VPDB \% scale using international standards NBS19 and LSVEC via two-point normalization.

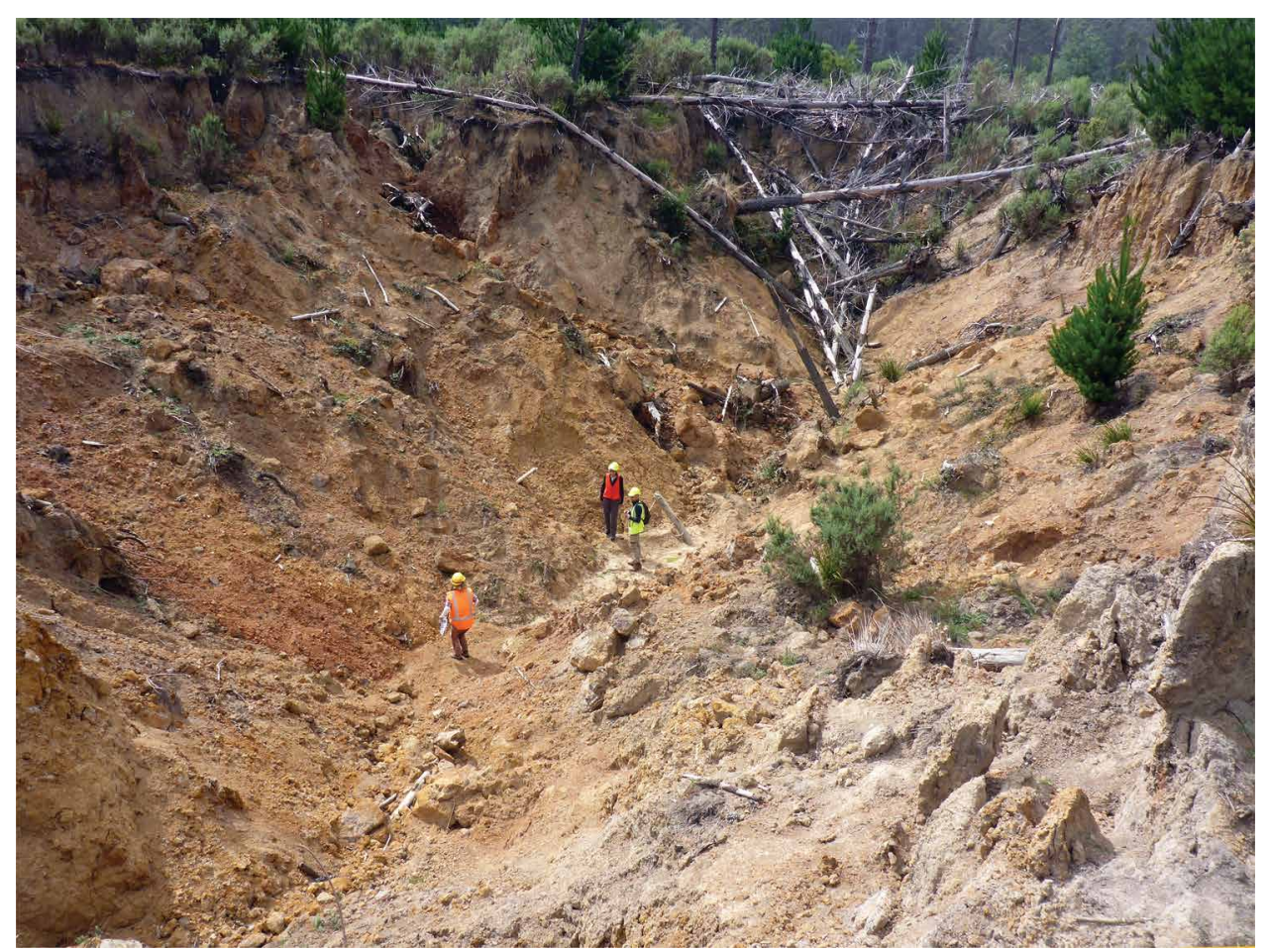

Figure 3. Sinkhole 1 in March 2019. This sinkhole formed in the winter of 2016 when several smaller sinkholes formed in 2013-2015 coalesced. It is the largest in the study area at over 60 $\mathrm{m}$ wide and $10 \mathrm{~m}$ deep with a footprint of $1450 \mathrm{~m}^{2}$. An estimated $6000 \mathrm{~m}^{3}$ of soil derived from Quaternary deposits have been lost to the underlying karst at this site. The furthest figure is standing on an exposure of limestone bedrock with a small cave entrance into which runoff flows during heavy rainfall.

\section{Results}

\section{Field Surveys and Sinkhole Monitoring}

Mapped sinkholes are shown in Fig. 2. The first sinkhole noted (sinkhole 2; Fig. 2) formed before harvest operations. At the time of first inspection in January 2011, it was approximately $20 \mathrm{~m}$ diameter and $4 \mathrm{~m}$ deep. By August 2011, it had expanded to $27 \mathrm{~m}$ diameter and $7 \mathrm{~m}$ deep. Between January 2011 and July 201814 sinkholes formed in the study area, including Sinkhole 1 (Fig. 3) and Sinkhole 3 (Fig. 4) that formed catastrophically over a weekend in 2013. Since 2016, there has been a rapid increase in sinkhole numbers with a second sinkhole cluster forming at the northern end of the plantation (Fig. 2), as well as several isolated features. As previously mentioned, the date of initial collapse of most sinkholes in the study area is unknown. The sinkholes that have formed since 2016 appear to have collapsed during the winter months of May- 


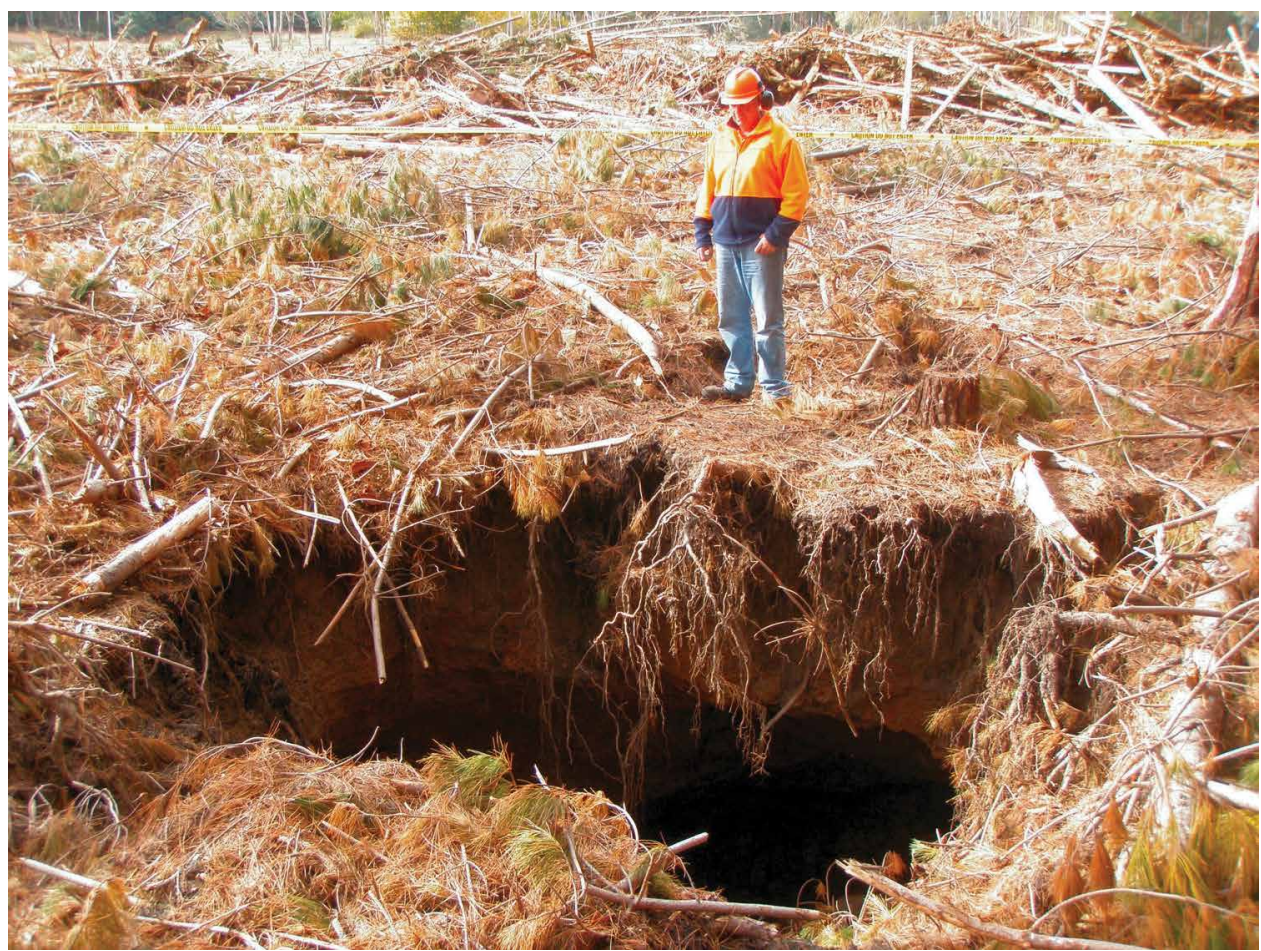

Figure 4. A contractor standing on the edge of a sinkhole (the precursor to sinkhole 3, Fig. 2), which formed between the close of the week's work on Friday April 19, 2013 and the return of contractors on Monday April 22, 2013. The contractor is standing on vehicle tracks - a harvesting machine had crossed the area of the sinkhole on the previous Friday.

The streams at CCS, ECS and CCC have different seasonal behaviour (Fig. 5). The flow in Caroline Creek at CCS is seasonally variable $(\mu=0.46, \sigma=0.45 \mathrm{~m} / \mathrm{s})$ : large flow peaks follow high rainfall and there is a gradual increase in to-

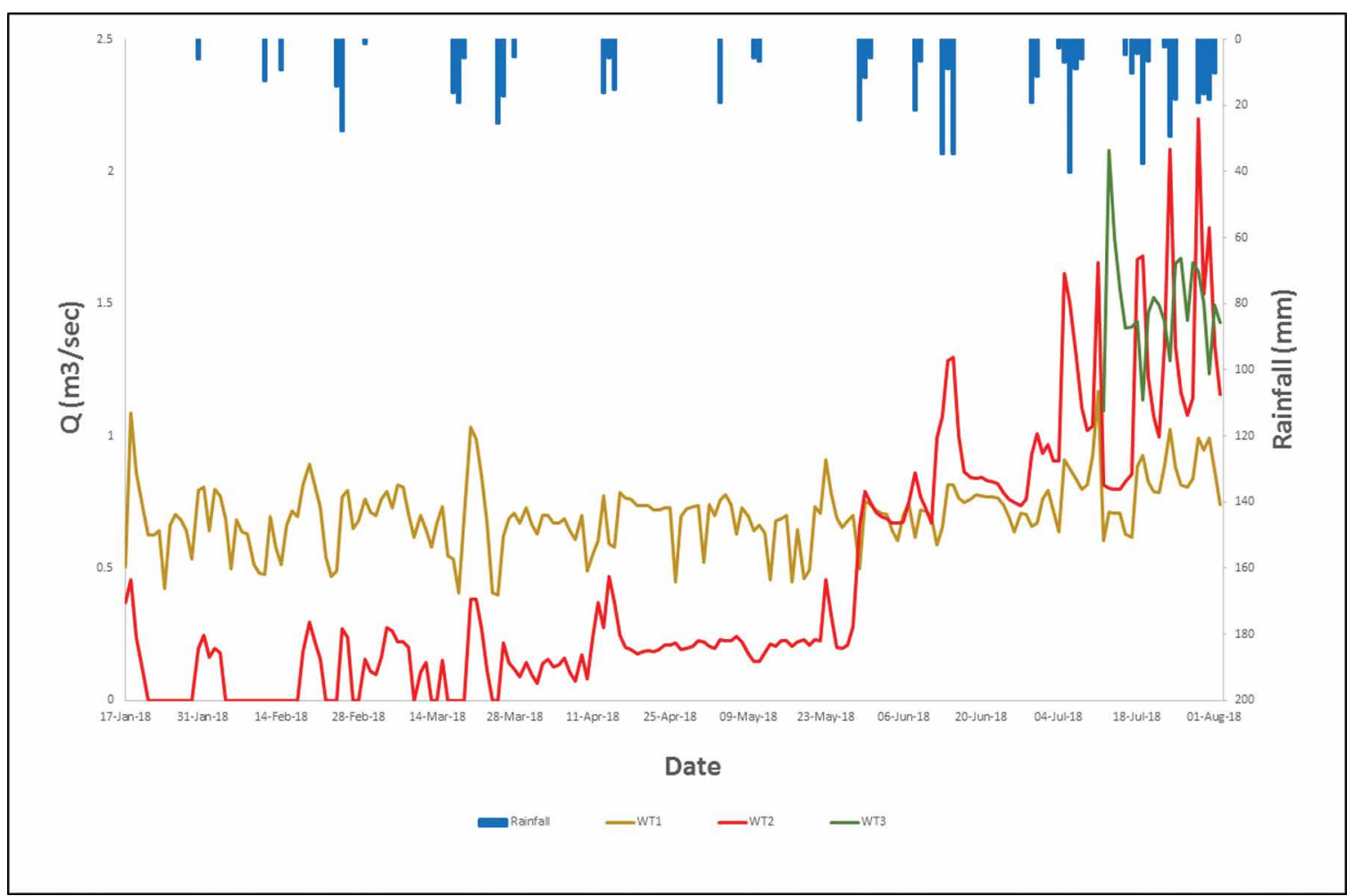

Figure 5. Flow records for Eastern Creek at ECS (brown line), Caroline Creek at CCS (red line) and Caroline Creek at DSS (green line), January 17, 2018 to July 31, 2018. Note the relatively uniform flow of Eastern Creek and the seasonal flow of Caroline Creek. Daily rainfall $(\mathrm{mm})$ shown as blue bars.
August. During heavy rain in July 2017 rapid lateral sinkhole expansion of sinkhole 2 by gully erosion and slumping was observed indicating that it is likely that most sinkhole expansion follows wet weather. Between June 2015 and July 2018 all sinkholes expanded and new sinkholes formed (Fig. 2). Although cave entrances were noted during surveys, specifically at Caroline Creek Streamsink (CCS) and in Blue Lake (BL) when dry, the hazard of overburden collapse prevented any cave exploration.

\section{Flow And Rainfall}

Flow calculations using Manning's equation were compared to flow measured in situ. Estimated flows at CCS exceeded measured flows by $14 \%$, were lower than measured flows at ECS by $4 \%$ and were lower than measured flows at CCC by $15 \%$ (i.e., the two techniques produced results within $15 \%$ of each other).

tal flow as winter progresses (Fig. 5). From June to July average flow increased by $1.27 \mathrm{~m}^{3} \quad \mathrm{~s}^{-1}$ relative to the January-April average of $0.2 \mathrm{~m}^{3}$ $\mathrm{s}^{-1}$. In summer Caroline Creek is generally dry. Eastern Creek flows continuously (Fig. 5). At ECS Eastern Creek has relatively consistent diurnal flow peaks and troughs measured from January to April ( $\mu$ $=0.57, \sigma=0.10$ $\mathrm{m}^{3} \mathrm{~s}^{-1}$ ), probably related to pumping cycles at the nearby limestone 
quarry; from June to July maximum flow increased only by $0.15 \mathrm{~m}^{3} \mathrm{~s}^{-1}$ relative to the January-April average. High flow of Eastern Creek during periods of higher rainfall (May-July) matches that of Caroline Creek (Fig. 5).

\section{Dye-Tracing Results}

No background dye was detected in any stream prior to dye-tracing experiments.

\section{Experiment 1}

Fluorescein dye was injected into Caroline Creek at Caroline Creek Streamsink (CCS) on June 7, 2017 during low flow (defined as occurring when all of the flow of Caroline Creek enters Caroline Creek Streamsink and no flow continues overland). Charcoal bags were collected after 2 days and 7 days immersion. Dye was detected at both Youngmans Road (YR) and at Dawsons Siding (DS) (Fig. 6, Experiment 1). Flow rates were not recorded during this initial experiment but dye arrived at YR and DS in less than $48 \mathrm{~h}$. Higher dye concentrations were recorded at YR (0.16 NC-ppb) than at DS (0.0048 ppb). The experiment showed that a subsurface connection exists between the Caroline Creek Streamsink (CCS) and the upper reaches of Eastern Creek (YR).

\section{Experiment 2}

Fluorescein dye was injected upstream of Eastern Creek Streamsinks (ECS) on January 16, 2018 during low flow when some water was flowing north in the surface channel and some was sinking into Eastern Creek Streamsinks (ECS). Charcoal bags were collected at the following times after injection: Mersey River (MR) 18 and $162 \mathrm{~h}$; Dawsons Siding (DS) 3, 18, 65 and 162 h; Youngmans Road (YR) 4, 18, 42, 65 and 162 h; and Redwater Creek (RC) 66 and 161 h. Dye was detected at both Eastern Creek at Youngmans Road (YR) and Caroline Creek at Dawsons Siding (DS). Flow in Eastern Creek at ECS was recorded as approximately $0.41 \mathrm{~m}^{3} \mathrm{~s}^{-1}$. Dye arrived at YR in under $18 \mathrm{~h}$ and at DS between 6 and $18 \mathrm{~h}$. Higher concentrations of dye were recorded at DS (2.174 NC-ppb) than at YR (0.033 NC-ppb) (Fig. 6, Experiment 2). Small concentrations of fluorescein were recorded in the Mersey River (MR) (0.006 NC-ppb) and no dye was recorded at Redwater Creek $(R C)$. The experiment showed that a subsurface connection exists between the Eastern Creek Streamsinks

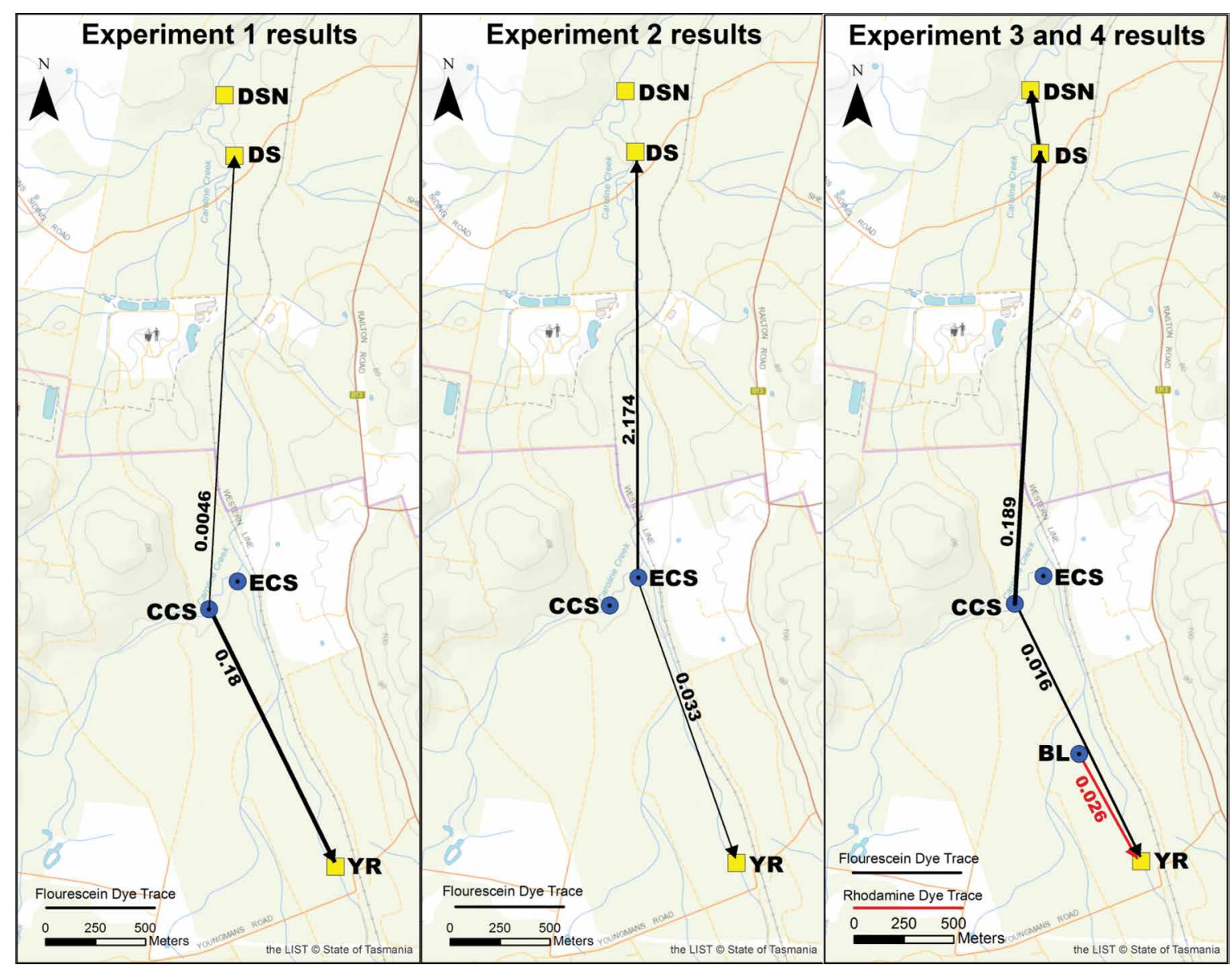

Figure 6. Dye-tracing results for Experiments 1, 2, 3, and 4. Blue circles are dye injection points and yellow squares are sampling sites. Normalized dye concentrations (NC-ppb) are shown next to arrows. Bold arrows indicate dominant flows. Note that Experiments 1 and 2 were conducted during low flows, and Experiments 3 and 4 during high flows.
(ECS) and the upper reaches of Eastern Creek (YR) but no connection exists between ECS and Redwater Creek (RC).

\section{Experiment 3}

Rhodamine WT dye was injected into the sinkhole informally named Blue Lake (BL) on July 26, 2018 (Fig. 6, Experiment 3 and Fig. 7) when flow into Blue Lake (from an overflowing Eastern Creek) was estimated to be 5-7 $\mathrm{L} \mathrm{s}^{-1}$. At the time of injection water was ponded in the sinkhole. Two days later water had completely drained into a visible cave at the base of Blue Lake. $0.026 \mathrm{ppb}$ 


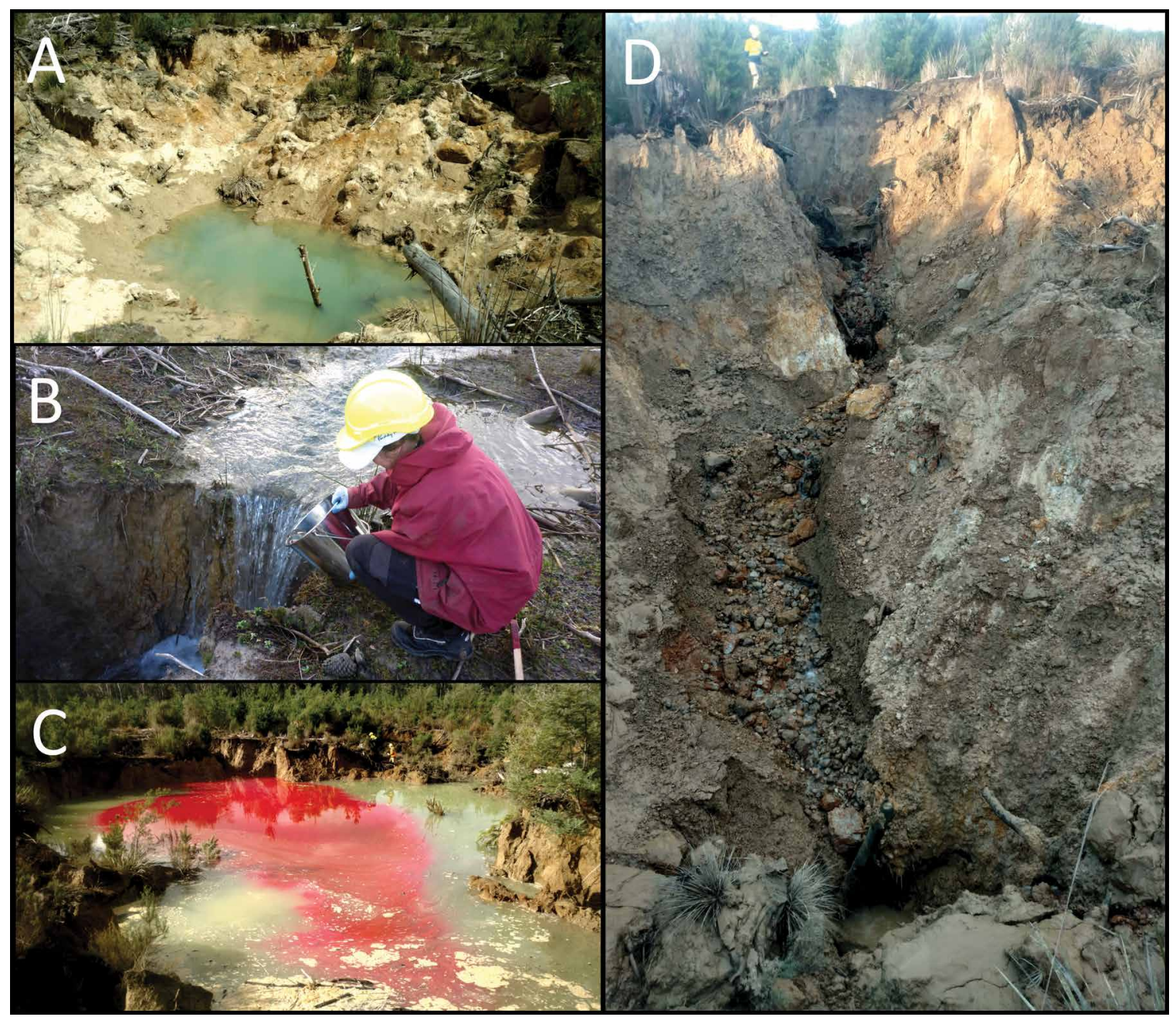

Figure 7. A. After heavy rain a lake (informally named Blue Lake) forms in Sinkhole 4 (photographed October 26, 2017); a small stream. B. (estimated flow 5-7 L/s) originating from a flooded Eastern Creek flows into it (photographed 26 July 2018). C. $870 \mathrm{~g}$ of Rhodamine WT dye was injected into this stream on July 26, 2018. D. By the afternoon of Saturday July 28, 2018 the lake had completely drained and the stream was seen cascading into an unstable vertical shaft at the base of the sinkhole which was over $7 \mathrm{~m}$ deep. The shadow line marks the approximate previous water level as shown in $\mathrm{C}$. of Rhodamine dye was detected in charcoal bags at $\mathrm{YR}$ between 22 and $48 \mathrm{~h}$ following injection (Fig. 6, Experiment 3). Rhodamine dye was not detected at DSS. No dye was recorded at Redwater Creek (RC). The experiment showed that a subsurface connection exists between Blue Lake and the upper reaches of Eastern Creek (YR) but no connection exists between $\mathrm{BL}$ and Redwater Creek (RC).

\section{Experiment 4}

Fluorescein dye was injected into the Caroline Creek Streamsink (CCS) on July 27, 2018 during high flow. Approximately one-third of flow was estimated to be entering the streamsink and two thirds to be flowing down the Caroline Creek surface channel. Charcoal bags were collected at the following times after injection: Dawson Siding (DS) $25 \mathrm{~h}$ and $172 \mathrm{~h}$; Youngmans Road (YR) $1 \mathrm{~h}, 27 \mathrm{~h} 48 \mathrm{~h}$ and $171 \mathrm{~h}$; Caroline Creek (CC) upstream of CCS 14 h; Redwater Creek (RC) 169 h. Caroline Creek (CCS) flow was approximately $1.08 \mathrm{~m}^{3} \mathrm{~s}^{-1}$. At YR $0.016 \mathrm{NC}$-ppb of fluorescein was detected (Fig. 6, Experiment 4) which is one-tenth of that observed during low flows (Fig. 6, Experiment 1), despite the concentration of fluorescein being injected being twice that injected in experiments 1 and 2 (Table 1). Most of the dye travelled downstream as surface flow to Dawsons Siding North (DSN) where high concentrations of $0.189 \mathrm{NC}$-ppb were recorded in under $25 \mathrm{~h}$. The fluorescein dye reached Eastern Creek at YR from Caroline Creek Streamsink (CCS) within $1.25 \mathrm{~h}$.

Fluorescein was first detected at DSN $4.9 \mathrm{~h}$ after injection by the fluorimeter and in the activated charcoal bags at DS at $25 \mathrm{~h}$. A peak concentration of $6565 \mathrm{ppb}$ was recorded in the fluorimeter (peak not shown in Fig. 8). Flow velocity was estimated as $0.15 \mathrm{~m} \mathrm{~s}^{-1}$ based on the surface distance between CCS and DSN (c. $2720 \mathrm{~m}$ ). Four secondary peaks were detected at $52.1 \mathrm{~h}(168 \mathrm{ppb}), 92.2 \mathrm{~h}(124 \mathrm{ppb}), 105.1 \mathrm{~h}(123 \mathrm{ppb})$ and $132.5 \mathrm{~h}(87 \mathrm{ppb})$ (Fig. 8). These concentration peaks correspond with flow peaks in Caroline Creek (CCS) and Eastern Creek (ECS) upstream of their confluence and in Caroline Creek downstream of the confluence (CCC) (Fig. 8). The time interval between the consecutive five peaks was $46 \mathrm{~h}, 13 \mathrm{~h}, 41 \mathrm{~h}$ and $27 \mathrm{~h}$ (Fig. 8). The experiment confirmed the Experiment 1 result that a subsurface connection exists between Caroline Creek Streamsink (CCS) and the upper reaches of Eastern Creek (YR) and enabled flow rates to be estimated (see Discussion and Conclusions).

No dye was detected in Caroline Creek upstream of the streamsink (CCS) or in Redwater Creek (RC). 


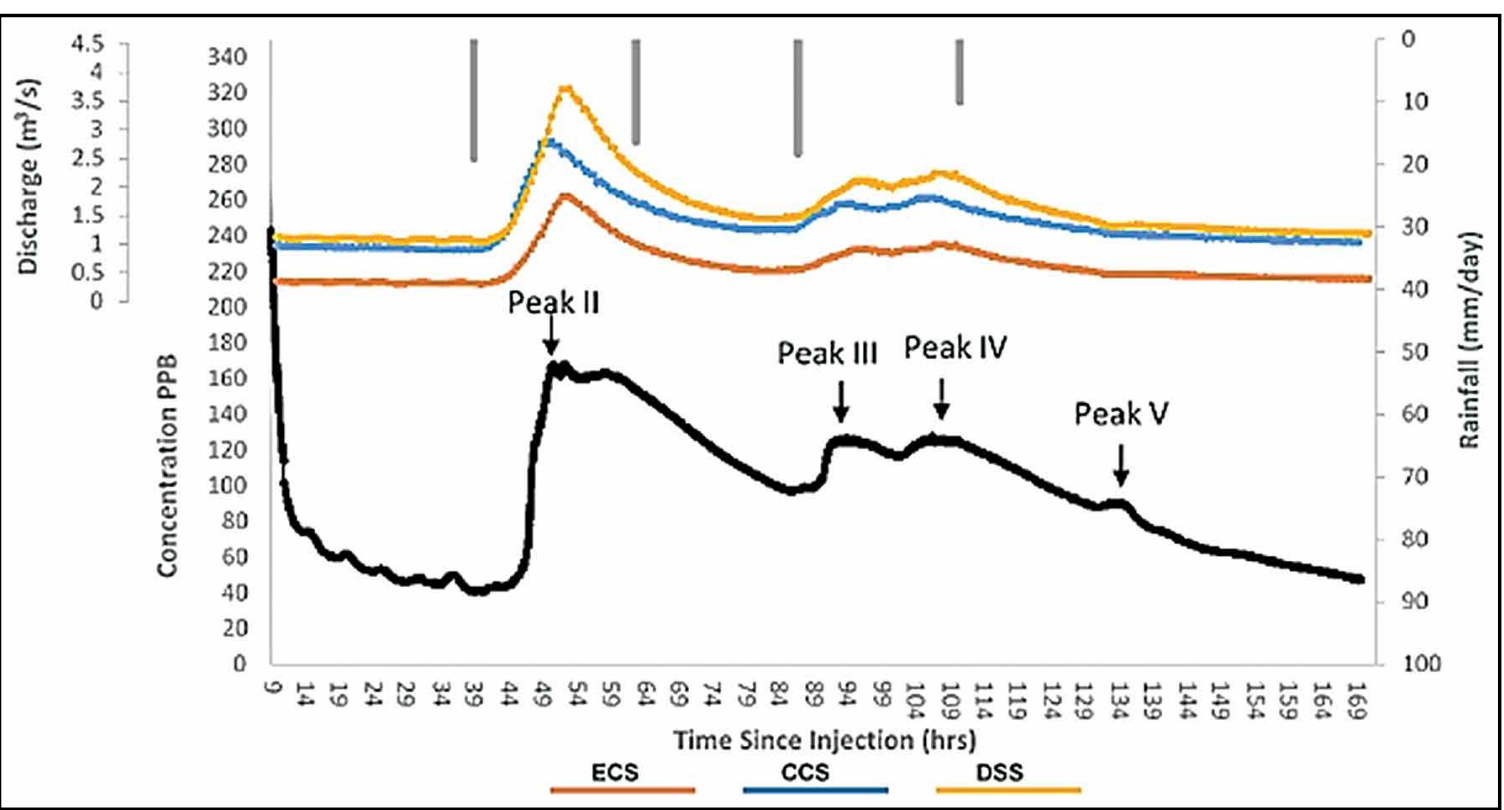

Figure 8. Fluorimeter dye trace record for Caroline Creek at DSN following fluorescein dye injection at CCS on July 27,2018 . The first peak occurred at $4.9 \mathrm{~h}$ and is not shown. The record illustrated covers the period $9-169 \mathrm{~h}$ following dye injection. Flow rates at ECS, CCS, and DSS are given on the y axis. Daily rainfall (mm/day) is shown by grey bars.

Table 2. Date and location of samples taken for water chemistry.

\begin{tabular}{ccc}
\hline Date & $\begin{array}{c}\text { Sample Location } \\
\text { (Figure 2) }^{\mathbf{a}}\end{array}$ & $\begin{array}{c}\text { Sample Notation } \\
\text { s = summer; w = winter }\end{array}$ \\
\hline Jan. 16, 2018 & DSN & DSNs \\
Jan. 16, 2018 & YR & YRs \\
July 27, 2018 & DS & DSw \\
July 27, 2018 & CCS & CCSw \\
July 27, 2018 & YR & YRw \\
July 28, 2018 & BL & BLw \\
\hline
\end{tabular}

a YR = Youngmans Road; DS = Dawsons Siding; DSN = Dawsons Siding North; BL = Blue Lake; CCS = Caroline Creek Streamsink.

${ }^{\mathrm{b}}$ The sample site was upstream of the streamsink
Water Chemistry

$\mathrm{S}$ a m p I e s were taken from Caroline Creek and Eastern Creek in summer 2017/2018 and winter 2018 (Table 2). The water chemistry results and in situ parameters such as temperature, $\mathrm{pH}$ and electrical conductivity of water samples are shown in Table 3 .

Electrical conductivity (EC) of the water samples ranges from $98 \mu \mathrm{S} \mathrm{cm}^{-1}$ to $503 \mu \mathrm{S} \mathrm{cm}^{-1}$ (Table 3). The Caroline Creek water immediately upstream of the Caroline Creek Streamsink (CCSw) has the lowest EC values recorded (98 $\mu \mathrm{S} \mathrm{cm}^{-1}$ during winter). There was no flow in Caroline Creek during summer. Highest EC values were recorded in Eastern Creek (YRs) $\left(485 \mu \mathrm{S} \mathrm{cm}{ }^{-1}\right)$ and Caroline Creek at Dawsons Siding North (DSNs) $\left(503 \mu \mathrm{S} \mathrm{cm}^{-1}\right)$ in summer (Table 3 ). The $\mathrm{pH}$ values of the sampled waters range from 7.0 to 8.6 with higher values corresponding to higher EC values. In all

Table 3. Water chemistry, electrical conductivity, $\mathrm{pH}$ and temperature during low summer flows and high winter flows.

\begin{tabular}{|c|c|c|c|c|c|c|c|c|}
\hline \multirow[b]{3}{*}{ Parameter } & \multicolumn{8}{|c|}{ Site (Figure 2) ${ }^{\mathrm{a}}$ and season } \\
\hline & \multicolumn{2}{|c|}{ YR } & \multicolumn{2}{|c|}{ DSN } & \multicolumn{2}{|c|}{ BL } & \multicolumn{2}{|c|}{ CCS } \\
\hline & $\mathbf{s}$ & $\mathbf{w}$ & $\mathbf{s}$ & $\mathbf{w}$ & $\mathbf{s}$ & $\mathbf{w}$ & $\mathbf{s}$ & $\mathbf{w}$ \\
\hline Temp. $\left({ }^{\circ} \mathrm{C}\right)$ & 23 & 12 & 19 & 9 & $\ldots$ & 10 & $\cdots$ & 7 \\
\hline $\mathrm{pH}$ & 7.8 & 8.6 & 7.8 & 7.5 & $\cdots$ & 8.2 & $\cdots$ & 7.0 \\
\hline Conductivity $(\mu \mathrm{S} / \mathrm{cm})$ & 485 & 438 & 503 & 195 & $\cdots$ & 405 & $\cdots$ & 198 \\
\hline $\mathrm{Ca}^{2+}(\mathrm{mg} / \mathrm{L})$ & 63 & 70 & 75 & 43 & $\ldots$ & 60 & $\cdots$ & 5 \\
\hline $\mathrm{Mg}^{2+}(\mathrm{mg} / \mathrm{L})$ & 6.1 & 6.3 & 5.9 & 4.5 & $\cdots$ & 5.6 & $\cdots$ & 2.6 \\
\hline $\mathrm{Na}^{+}(\mathrm{mg} / \mathrm{L})$ & 21 & 11 & 20 & 11 & $\cdots$ & 11 & $\cdots$ & 10 \\
\hline $\mathrm{K}^{+}(\mathrm{mg} / \mathrm{L})$ & 2.9 & 3.0 & 1.4 & 2.1 & $\cdots$ & 2.3 & $\cdots$ & 2.0 \\
\hline $\mathrm{Cl}^{-}(\mathrm{mg} / \mathrm{L})$ & 30 & 19 & 27 & 20 & $\cdots$ & 20 & $\cdots$ & 17 \\
\hline $\mathrm{SO}_{4}{ }^{2-}(\mathrm{mg} / \mathrm{L})$ & 41 & 42 & 30 & 29 & $\cdots$ & 41 & $\cdots$ & 9 \\
\hline $\mathrm{HCO}_{3}{ }^{-}(\mathrm{mg} / \mathrm{L})$ & 139 & 139 & 140 & 84 & $\cdots$ & 115 & $\ldots$ & 4 \\
\hline$\delta^{18} \mathrm{O}(\%)$ & -5.2 & -5.2 & -5.1 & -5.1 & $\cdots$ & -5.1 & $\cdots$ & -2.4 \\
\hline$\delta^{2} \mathrm{H}(\% 0)$ & -27 & -28 & -26 & -28 & $\cdots$ & -29 & $\cdots$ & -13 \\
\hline$\delta^{13} \mathrm{C}(\% 0)$ & $\cdots$ & -10.5 & $\cdots$ & -12.3 & $\cdots$ & -11 & $\cdots$ & -11.4 \\
\hline
\end{tabular}

\footnotetext{
a YR = Youngmans Road; DSN = Dawsons Siding North; BL = Blue lake; CCS = Caroline Creek Streamsink; $\mathrm{s}=$ summer; $\mathrm{w}=$ winter.
} 
but CCSw samples water chemistry is dominated by $\mathrm{Ca}^{2+}$ and $\mathrm{HCO}_{3}^{-}$ions: $\mathrm{Ca}^{2+}$ concentrations are $5 \mathrm{mg} \mathrm{L}^{-1}$ in $\mathrm{CCSw}^{-}$ samples but are in the range $43-75 \mathrm{mg} \mathrm{L}^{-1}$ in all other samples. Likewise, $\mathrm{HCO}_{3}{ }^{-}$concentrations are $4 \mathrm{mg} \mathrm{L}^{-1}$ in CCSw samples but in the range $84-140 \mathrm{mg} \mathrm{L}^{-1}$ in all other samples. $\mathrm{SO}_{4}{ }^{2-}$ values follow the same pattern: concentrations are $9 \mathrm{mg} \mathrm{L}^{-1}$ in CCSw samples and $29-42 \mathrm{mg} \mathrm{L}^{-1}$ in all other samples. $\mathrm{Mg}^{2+}$ concentrations are $2.6 \mathrm{mg} \mathrm{L}^{-1}$ in CCSw water but about double (range 4.5-6.3 mg L${ }^{-1}$ ) in all other samples. $\mathrm{Na}^{+}$and $\mathrm{K}^{+}$and $\mathrm{Cl}^{-}$concentrations are similar in all samples, but $\mathrm{Na}^{+}$and $\mathrm{Cl}^{-}$dominate the ionic composition of CCSw water because of the low levels of other ions.

Samples YRw, YRs, DSNw, DSNs and BLw have chemistry typical of carbonate waters with $\mathrm{HCO}_{3}{ }^{-}$and $\mathrm{Ca}^{2+}$ as the dominant ions (Knöll and Scheytt, 2018) and pH values in the range of 7.5-8.6 (Table 3). During summer and winter Caroline Creek (downstream of its confluence with Eastern Creek) and Eastern Creek (DSNs, DSNw) and YRs and YRw samples have similar major ion compositions; concentrations of $\mathrm{Na}^{+}$and $\mathrm{Cl}^{-}$are higher in summer. DSNs water is very similar to YRs water but has slightly higher $\mathrm{Ca}^{2+}$ concentration. The Blue Lake water during winter (BLw) is similar to the $\mathrm{YRw}$ water from which it is largely derived by overland flow, the lower values for $\mathrm{pH}$, conductivity, $\mathrm{Ca}^{2+}, \mathrm{Mg}^{2+}, \mathrm{K}^{+}$ and $\mathrm{HCO}_{3}^{-}$in $\mathrm{BLw}$ probably are due to dilution by rainwater.

Water stable isotope ratios for $\delta^{18} \mathrm{O}$ and $\delta^{2} \mathrm{H}$ for all samples fall on the Local Meteoric Waterline (LMWL) for Cape Grim, Tasmania (Fig. 9). At Cape Grim (162 km northwest of Railton) the variability of $\delta^{18} \mathrm{O}$ and $\delta^{2} \mathrm{H}$ isotope ratios in rainfall is reflected by enriched $\delta^{18} \mathrm{O}$ isotopes in summer and depleted $\delta^{18} \mathrm{O}$ isotopes in winter by a factor of approximately \pm -5 (GNIP, 2018). Stable isotope ratios from samples taken in winter are depleted with respect to average rainfall isotope composition and range from $-5.2 \%$ to $-5.1 \%$ for $\delta^{18} \mathrm{O}$ and $-28 \%$ to $-25 \%$ for $\delta^{2} \mathrm{H}$, respectively. Water in samples from the Blue Lake sinkhole (BLw), Caroline Creek downstream of the recharge zone and confluence (DSNw) and Eastern Creek upstream of the recharge zone and confluence (YRw) are slightly more depleted in winter with values of $-5.1 \%,-5.1 \%$ and $-5.2 \%$ for $\delta^{18} \mathrm{O}$ and $-29 \%,-25 \%$ and $-28 \%$ for $\delta^{2} \mathrm{H}$, respectively. During both summer and winter Eastern Creek (YR) has depleted isotope signatures reflecting winter rainfall with values of $-5.2 \%$ o $\delta^{18} \mathrm{O}$ and -28 $\% \delta^{2} \mathrm{H}$ in winter and $-5.0 \% \delta^{18} \mathrm{O}$ and $-27 \% \circ \delta^{2} \mathrm{H}$ in summer, respectively.

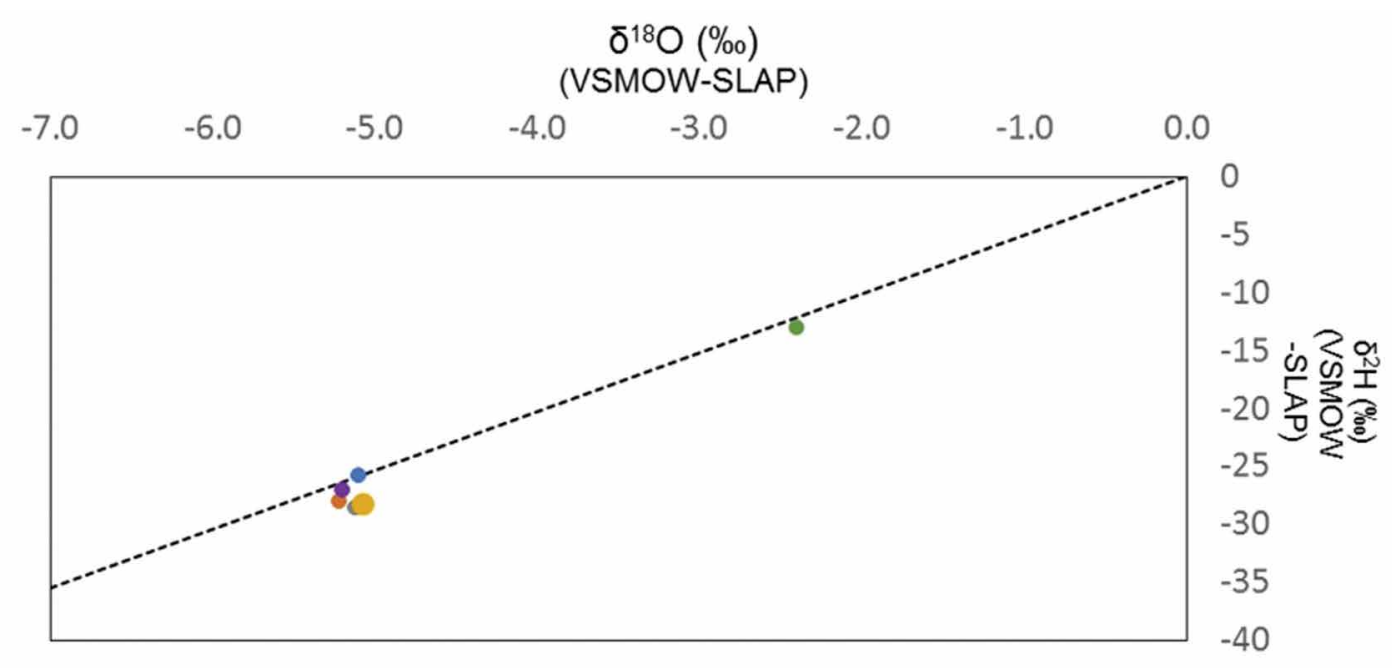

- YRw - BLw - DSNw - YRs - CCSw - DSNs-----LMWL

Figure 9. Water-stable isotopes of stream samples, plotted on the LMWL (Cape Grim, Tasmania; Liu et al. 2010).
Carbon isotope ratios $\left(\delta^{13} \mathrm{C}\right)$ were determined for winter samples only (Table 3). The $\delta^{13} \mathrm{C}$ ratios range from -16.2 $\%$ to $-10.5 \%$. There is a direct positive correlation between $\mathrm{Ca}^{2+}$ concentrations and $\delta^{13} \mathrm{C}$ isotope ratios. Eastern Creek (YRw), Blue Lake (BLw) and Caroline Creek downstream of the recharge zone and confluence (DSNw) have the

highest concentrations of $\mathrm{Ca}^{2+}$ and highest $\delta^{13} \mathrm{C}$ ratios of $-10.5 \%,-11 \%$, $-12.3 \%$ and $-11.4 \%$ respectively. Caroline Creek upstream of the recharge zone and confluence (CCSw) water is less enriched in $\delta^{13} \mathrm{C}(-16.2 \%)$ and has comparatively low $\mathrm{Ca}^{2+}$ concentrations.

Isotope data (Table 3; Fig. 10) shows that with the exception of sample CCSw, taken from Caroline Creek stream above the streamsink in July (winter), all stream samples taken in both winter and summer have similar $\delta^{18} \mathrm{O}$ and $\delta^{2} \mathrm{H}$ isotopic composition and plot together.

\section{Karst Disturbance Index}

Van Beynen and Townsend (2005) developed a karst disturbance index which North et al. (2009) applied (in slightly modified form) to karst landscapes of Florida and southeast Italy. In the Railton study area, the usefulness of the index is hampered by the lack of data for many indicators used. For example, no information is available on the condition of 


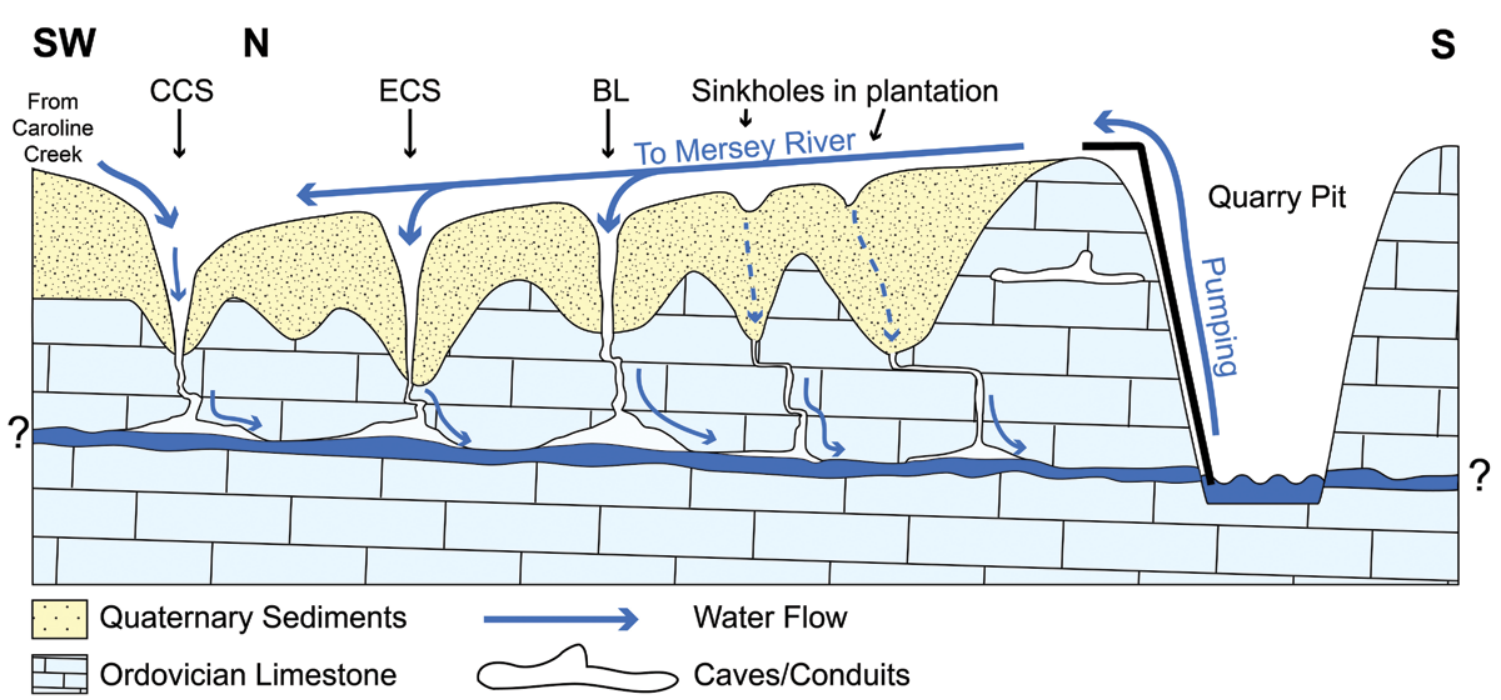

Figure 10. Diagrammatic representation of surface and subsurface flows induced by intersection of cave system at Dulverton Pit and pumping of water from Dulverton Pit to the headwaters of Eastern Creek. Not to scale. This representation is a simplification and the cave system involved may have multiple stream channels. the caves before human land-use changes of either Aboriginal or European origin or on the condition of stream microbiota. Consequently, only 5 of the 30 criteria listed by North et al. (2009) could be assessed with any confidence on the 0-3 scale used. Maximum scores of 3 (North et al., 2009) were assigned to three severity indicators: quarrying ("large open-cast mines"); erosion ("severe" on account of large sinkhole initiation); and "changes in water table" (likely to exceed $35 \mathrm{~m}$ ). A score of 2 was assigned to regulatory protection ("weak regulations": the Tasmanian Water Management Act (1999, section 51), is not specific about controlling the effects of quarrying on groundwater). A score of 1 was applied to road building ("some country lanes"). Tires have been dumped in one sinkhole at Railton, but this observation was not included in the disturbance index assessment because scores for industrial pollution chiefly concern liquid pollutants such as oils and water-soluble chemicals (Van Beynen and Townsend, 2005; North et al., 2009). Such contaminants were not noted in Railton sinkholes, although they could present a risk to water quality in the future as they have done elsewhere (Delle Rose et al., 2007; Parise, 2016). The tally of 12 out of a possible 15 gives a karst disturbance index value of 0.8 ("highly disturbed").

\section{Discussion and Conclusions}

\section{Sinkhole Characteristics}

All the sinkholes noted are cover-collapse sinkholes (Fig. 3 and 4). Sinkholes in the study area tend to concentrate and enlarge along the major syncline fold axis $\left(340^{\circ}\right)$ implying that limestone dissolution (the ultimate control of sinkhole formation) is preferentially occurring along the syncline fold axis, as noted by Yan et al. (2008) and Goldscheider and Neukum (2010). Elsewhere sinkholes occur, often in a linear pattern, where limestone permeability is highest (e.g. Lolcama et al., 2002; Basso et al., 2013; Pepe and Parise, 2014; Kobal et al., 2015; Siska et al., 2016). Although the sinkholes in the study area were commonly circular in plan at the time of initial collapse, they elongate along the trend of karst drainage as a result of gradual soil loss by suffusion processes into the underlying karst aquifer, as described by Zhou and Beck (2008).

Cover-collapse sinkholes are particularly common in areas where more cohesive layers overlie less consolidated deposits (Tharp, 1999) and in areas like the Railton valley where thick deposits (usually sedimentary) mantle karst (Noury et al., 2018; Intrieri et al., 2018). Langer (2001) cited several studies that showed that cover-collapse sinkholes were most likely to form when the water table first declines past the bedrock/soil contact in areas where the unconsolidated sediments overlying limestone are 5-30 m thick as in the Railton area, although other factors like the nature of the clay fraction in the sediments also influence the risk of sinkhole forming. Because cover-collapse sinkholes generally develop from the limestone surface up into the cover sediments (Kaufmann and Quinif, 2002; Soliman et al., 2018) surface collapse is unpredictable, creating an environmental hazard (Waltham, 2008), particularly for machines (Fig. 4).

\section{Subsurface Flows in Relation to Dulverton Pit}

Dye experiments 1 and 2 clearly demonstrated that during low stream flows subsurface flow occurs between both the Caroline Creek Streamsink (CCS) and Eastern Creek at Youngmans Road (YR) and between the Eastern Creek Streamsinks (ECS) and Eastern Creek at Youngmans Road (YR) (Fig. 6), approximately following the limestone syncline axis. For flow from both streamsinks to enter the subsurface karst drainage system and then reappear upstream at a higher altitude ( $>5 \mathrm{~m}$ by surface mapping, but $>12 \mathrm{~m}$ if streamsink depth is taken into account), the subsurface flow 
must be pumped to higher elevation, i.e. pumping of incoming water in Dulverton Pit into Eastern Creek headwaters, to maintain dry conditions in the quarry, is responsible for the circulation of dye to the upper (southern) reach of Eastern Creek. Pumping has created a zone of low hydraulic pressure in the south of the study area at the limestone quarry (Dulverton Pit), where the base of the quarry is approximately $60 \mathrm{~m}$ below sea level (Google Earth, 2016 imagery). We conclude that quarry deepening and regular dewatering has caused a localized reduction in hydraulic head and a draw-down of the regional water table, as previously shown by Langer (2001). This has resulted in the formation of a cone of depression (Langer, 2001; Lolcama et al., 2002). Cones of depressions around limestone quarries can extend laterally for more than $26 \mathrm{~km}$ (Langer, 2001). Therefore, given the closeness of the quarry to the streamsinks $(2.85 \mathrm{~km})$ it is highly likely that low hydraulic head at the quarry is causing groundwater flows to be directed south, in the opposite direction to natural surface flows. Flow is likely to occur through a large confined aquifer in a cave system, which would heighten the hydrologic gradient and rates of flow.

In the conceptualization outlined above the quarry site captures groundwater that is subsequently pumped into Eastern Creek and transported as surface flow downstream (Fig. 10). Surface water in Eastern Creek then re-enters the subsurface system via the streamsinks and the cycle continues, i.e. there is a continuous cycle of water from the quarry, to Eastern Creek, and back to the quarry. During high flow fluorescein dye injected into the Caroline Creek Streamsink (CCS) was detected in Eastern Creek (YR) within $1.25 \mathrm{~h}$, indicating a flow speed through the $4.6 \mathrm{~km}$ system (from CCS to Dulverton Pit to YR) of about $1 \mathrm{~m} / \mathrm{s}$ under high inflows. During low flows, when Caroline Creek does not flow consistently, field observations indicate that Eastern Creek is the dominant contributor to the karst aquifer (via the Eastern Creek streamsinks), although entry of water into the aquifer from the upper reaches of Caroline Creek (not investigated) cannot be excluded. Because water is recycled in this way, the quarry requires dewatering throughout the year so that the measured difference between quarry discharge at low and high flows is on average only $0.15 \mathrm{~m}^{3} \mathrm{~s}^{-1}$.

Experiment 3 shows that water entering Blue Lake (from Eastern Creek) also flows into Eastern Creek, higher in the catchment, at Youngmans Road (YR) and this observation is also readily explained by lower hydraulic pressure at the quarry and pumping of water into the upper reaches of Eastern Creek, i.e. drainage from sinkholes, as well as drainage from streamsinks feeds the same aquifer, and subsurface flow is via the subterranean aquifer (cave system) and Dulverton Pit.

\section{Water Chemistry}

The differences between the water chemistry of CCSw and water from YR, DSN and BL sites can be explained by CCSw flow being derived entirely from relatively fast overland flow of meteoric water with little mineral dissolution. In contrast DSNs, DSNw, YRs, YRw and BLw water analyses all show evidence of calcite dissolution (high concentrations and a molar ratio of 1:2 of $\mathrm{Ca}^{2+}$ and $\mathrm{HCO}_{3}{ }^{-}$). Thus, we conclude that the stream water at Youngmans Road (YRs and $\mathrm{YRw}$ ) and at points downstream (DSNs, DSNw and BLw) has all been influenced by subsurface flow through limestone. The lower levels of total dissolved solids (lower EC) and slightly lower pH in DSNw samples than in YRs, YRw and DSNs samples indicate dilution of DSNw water with direct runoff of meteoric water from Upper Caroline Creek (CCSw) flow. The source of the high $\mathrm{SO}_{4}{ }^{2-}$ in YRs and YRw water (Table 2) is unknown but may be gypsum used as a flocculant used on roads in the area or in the quarry. High $\mathrm{Mg}^{2+}$ is unlikely to originate from limestone dissolution as the limestone at Railton contains only $1.5 \% \mathrm{MgO}$ (Jennings, 1960). An alternative source is weathering of basalt and dolerite clasts derived from local outcrops within the Quaternary sediments. The range of $\mathrm{MgO}$ concentration in dolerite is large (1-11\%), but mean concentrations are c. $6 \%$ (Hergt et al., 1989) and similar MgO concentrations are found in basalts (Compston et al., 1968).

Oxygen isotope ratios are higher $\left(\delta^{18} \mathrm{O}=-2.4 \%\right)$ in Caroline Creek (CCSw) than in all other samples (Table 3, Fig. 9), most likely because the flow in Caroline Creek upstream of the streamsink is derived from meteoric water. The analysed sample, taken on July 27,2018 , may not be typical of winter rainfall, since it falls in the range of oxygen isotope ratios $\left(\delta^{18} \mathrm{O}=0\right.$ to $-3 \%$ ) typical of summer rainfall at Cape Grim, northwest Tasmania, rather than in the winter range $\left(\delta^{18} \mathrm{O}=-3\right.$ to $-6 \%$ ) (Liu et al., 2010) (Fig. 9).

All other samples group closely together, with more depleted oxygen and hydrogen isotope ratios indicating that most of these water samples are derived from winter rainfall. Isotope ratios in the field area deviate slightly from those for weighted average Cape Grim rainfall $\left(\delta^{18} \mathrm{O}=-4.0 \%\right.$ and $\delta^{2} \mathrm{H}=-21.5 \%$ ), which can be explained either by the distance of the field area from the coast, or the water in the karst system having accumulated over a shorter time period than that over which the Cape Grim average has been derived ( $\sim 20$ years average). As rainfall at Railton is highest in winter and evapotranspiration is highest in summer (when Caroline Creek often ceases to flow), water in the karst system is likely to be largely derived from winter rainfall, but whether it is derived largely from the previous winter's rainfall or over a longer period cannot be ascertained.

$\delta^{13} \mathrm{C}$ ratios for most waters are below the average ratios of recharge through soils $\left(-23\right.$ to $\left.-17 \% 0 \delta^{13} \mathrm{C}\right)$ indicating that chemical dissolution of the carbonates $\left(\delta^{13} \mathrm{C} \sim 0 \%\right.$ ) in the aquifer and rapid mixing has not only influenced the ionic 
composition of the water in the cave system (and all downstream water derived from it) but has also altered its isotopic composition.

\section{Seasonal Flow Variation}

Caroline Creek is a seasonally losing stream with periods of no or low flow $\left(\mu=0.16 \mathrm{~m}^{3} \mathrm{~s}^{-1}, \sigma=0.15 \mathrm{~m}^{3} \mathrm{~s}^{-1}\right)$ during January to April 2018 (Burke, 2018), when all flow immediately upstream of CCS flows into the CCS streamsink. From June to July 2018 Caroline Creek flow responds to rainfall and has more than double the average flow of Eastern Creek $\left(\mu=1.43 \mathrm{~m}^{3} \mathrm{~s}^{-1}\right)$. Losing streams of this nature are common in karst worldwide and indicate subsurface drainage (e.g., Lolcama et al., 2002; O'Driscoll and Dewalle, 2006). In contrast, Eastern Creek flows all year and has low overall flow variability $\left(\mu=0.57, \sigma=0.10 \mathrm{~m}^{3} \mathrm{~s}^{-1}\right)$, because of consistent pumping of groundwater from Dulverton Pit into Eastern Creek to maintain dry quarry conditions. Measurements during high flows between June 12, 2018 and July 3, 2018 indicate that the streamsinks in both Caroline Creek and Eastern Creek contribute averaged flow of $0.37 \mathrm{~m}^{3} \mathrm{~s}^{-1}$ into the subsurface system with peaks reaching $1.58 \mathrm{~m}^{3} \mathrm{~s}^{-1}$ (i.e., up to $48 \%$ percent of the combined flow in upstream Caroline and Eastern Creeks). This percentage exceeds the maximum autogenic inputs from losing streams measured by other studies (e.g., Scanlon et al., 2002). Therefore, surface-groundwater connectivity of the karst system is very high.

The fluorimeter results confirm the cycling of water between the streamsinks in Eastern Creek and Dulverton Pit. Five peaks in fluorescein concentration were observed at downstream Caroline Creek (DSN) following dye injection at the Caroline Creek streamsinks (CCS) during high flow (Fig. 9 shows the last four peaks). The initial and largest peak occurred $4.9 \mathrm{~h}$ after injection and is attributed to overland flow. (The dye had an approximate velocity of $0.21 \mathrm{~m} \mathrm{~s}^{-1}$ which is similar to the measured stream velocity of $0.31 \mathrm{~m} \mathrm{~s}^{-1}$.) As fluorescein is rapidly decomposed by sunlight and approximately $50 \%$ of fluorescein dye is decomposed within three hours of direct exposure (Feuerstein and Selleck, 1963), it is reasonable to conclude that any fluorescein still present in Caroline Creek surface water after the $4.9 \mathrm{~h}$ peak would have been destroyed by exposure to sunlight before the secondary peaks were recorded $50 \mathrm{~h}$ after injection. Therefore, the fluorescein dye must have been stored/transported underground following injection for it to be recorded in surface flow after $50 \mathrm{~h}$.

There are two possible explanations for the four secondary peaks in fluorescein concentration. (1) The peaks have been caused by pulses through the karst system resulting from fresh rainfall in the Caroline Creek catchment, an explanation apparently supported by the peaks corresponding with increased flow following rainfall (Fig. 8). However, although such an effect is common in monitored karst springs (e.g. Goldscheider et al., 2008; Filippini et al., 2018), it is unlikely that small pulses of rainfall feeding an aquifer could result in such clear secondary peaks. (2) The peaks are due to recirculation of the dye through the ECS-Dulverton Pit-YR-ECS circuit as a result of quarry pumping. This second explanation is supported by the fact that the peaks coincide with increased flows in Eastern Creek attributed to pumping from Dulverton Pit (Fig. 8). Explanation 2 is therefore more likely to be correct.

\section{Regional Karst Connections}

In Experiments 2, 3, and 4 the investigation was extended beyond the immediate study area to determine if dye injected into the karst aquifer system drained to points further afield (Burke, 2018), as Ordovician limestone covers an area of approximately $14 \mathrm{~km}^{2}$ within the study area and extends northwards to Latrobe and southwards to Kimberley (Kiernan, 1995b). No dye was detected at Redwater Creek (RC) after dye injection, either during low or high flows, indicating that, at present, subsurface drainage from the north does not continue south past Dulverton Pit. No dye was detected in any of the five northern streams during high flows (Burke, 2018). It is therefore unlikely that subsurface drainage continues to minor streams north of the study area. However, fluorescein was noted in charcoal bags installed in the Mersey River during low flows (Burke, 2018), the low value of 0.006 NC-ppb probably being due to downstream dilution of dye carried in Caroline Creek. Analysis of major ions support these dye tracing findings; none of the streams sampled outside the confines of the direct study area (Fig. 1) showed signs of calcite dissolution (Burke, 2018, appendix 3).

The hydrogeology results show that drainage in the Railton karst system is dominated by caves with high subsurface connectivity (Fig. 10). This type of karst system is best described as a 'dominant conduit model' (Vigna and Banzato, 2015; Filippini et al., 2018) in which (1) surface - groundwater connectivity is high and surface water rapidly infiltrates the system; (2) water is efficiently transported through the system by a network of connected subsurface conduits; and (3) flow is towards the zone of lowest hydraulic pressure. Preferential drainage routes are along weaknesses in the rock structure such as faults or folds.

\section{Sinkhole Formation Mechanisms in the Study Area}

Sinkholes close to the Railton railway were mapped by Matthews et al. (1983) and in 2003 by the FPA (N. Duhig, unpublished FPA report). Sinkholes close to the quarry first appeared on satellite imagery in 2007 and were relatively slow to form. Sinkhole formation appears to have accelerated by early 2011 when the first sinkholes were observed in the study area. According to Langer (2001) sinkholes can be triggered by events such as water level fluctuations, 
increased groundwater velocity and removal of vegetation. Thus, three triggering events can be hypothesised: (1) harvesting of the plantation with subsequent increased soil water saturation and water transmission to subsurface layers; (2) significant flooding after heavy rain in 2011 and 2016 resulting in opening of previously blocked drainage routes; and/ or (3) intersection of groundwater and subsurface conduits as a result of deepening of Dulverton Pit.

The study area was harvested in 2013. It is well-known that vegetation clearing removes root support. It also decreases transpiration losses and increases the percolation of surface water into karst aquifers, which can lead to enhanced dissolution (Kiernan, 2002; Urich, 2002). However, large sinkholes began to form before forest harvest and elsewhere plantation harvest in areas of cover-collapse sinkholes in Tasmania has been shown to have no detectable effect on sinkhole development (Slee et al., 2019). Furthermore, the harvest area was previously unforested (cleared) agricultural land and before European settlement was almost certainly covered by native forest which would have been subject to many forest-destroying natural and man-made fires over millennia. Neither fires nor clearing for agriculture has had an effect on the stability of the Quaternary sedimentary deposits. A significant effect of vegetation clearance on sinkhole formation is therefore discounted.

Rainfall at Railton in January 2011 was $201 \mathrm{~mm}$ (Bureau of Meteorology, 2019), which is more than three times the 15-year January mean of $60 \mathrm{~mm}$. In June 2016, rainfall was $238 \mathrm{~mm}$, which was more than double the 15-year June average of $102 \mathrm{~mm}$ (Bureau of Meteorology, 2019). Annual rainfall in 2011, 2013, and 2016 exceeded the long-term annual average of $1058 \mathrm{~mm}$ by $116 \mathrm{~mm}, 360 \mathrm{~mm}$, and $576 \mathrm{~mm}$ respectively. Aerial surveys show that two new sinkholes (sinkholes 7 and 8; Fig. 2) formed in the study area at Railton between 2015 and 2017 and may have formed after high rainfall in June 2016. However, the deviations of monthly rainfall from the mean, noted above, are not exceptional, and similar and higher rainfall totals, as well as numerous droughts, are likely to have occurred many times before records began, causing no collapse. For these reasons, we consider that high rainfall has not initiated sinkhole formation north of Youngmans Road, but episodes of high rainfall have probably accelerated erosion of existing sinkholes.

We conclude that the primary cause of sinkhole collapse at Railton is intersection of groundwater, and specifically a cave system, by the limestone quarry (Dulverton Pit), as predicted by Jennings (1959, p. 7) who warned that "the limestone [at Railton] has been shown by drilling and quarrying to contain fairly large underground cave systems, and if these were encountered below the level of the water table, they would certainly drain embarrassingly large quantities of water into the cut".

The proposed process for sinkhole formation in the study area is as follows: (1) the cone of depression around the quarry has lowered the water table and increased the thickness and extent of the vadose zone in the study area in a manner similar to that described by Langer (2001), Lolcama et al. (2002), Urich (2002), Hobbs and Gunn (2008), Heidari et al. (2011,) and Khanlari et al. (2012); (2) around 2010 to 2011 deepening of Dulverton Pit drained pre-existing caves around the quarry of water, including a cave system extending c. $3 \mathrm{~km}$ north of the quarry; (3) streamsinks and sinkholes formed because of the lowering of the water table and the consequent decline of hydraulic support for sediment overlying the limestone; (4) a proportion of stream water that normally flowed north then flowed south to the quarry (Figs. 6 and 10), carrying the sinkhole-derived sediment with it; (5) periods of high rainfall have resulted in sinkhole enlargements-higher stream turbidity in winter (TDS $=18.7$ NTU) than in summer (TDS = 2.5 NTU) (Burke, 2018) is attributed to greater sinkhole erosion and collapse during high winter rainfall and flushing of fine sediment from subsurface conduits by winter flows.

The cover-collapse sinkholes documented during this study are similar to sinkholes developed in other karst areas buried by thick Quaternary overburden deposits that have been impacted as a result of regional water table lowering. As mentioned in the Introduction, there are numerous examples of quarrying or withdrawal of water from aquifers lowering water tables and causing sinkholes to form in surrounding land, due to the removal of buoyant support for sediments or soils above the sediment/limestone contact (Kaufmann and Quinif, 2002; Parise and Pascali, 2003; Heidari et al., 2011; Khanlari et al., 2012; Jovanelly, 2014; Dell'Aringa et al., 2014; Jia et al., 2018; Pan et al., 2018). The process is well-illustrated in the review by Langer (2001, fig. 20b) and matches five steps in the process he describes: quarrying dewatering lowers the water table; a stream dries up (in this case two streams flow into streamsinks); underground cavities form in unconsolidated sediments due to loss of buoyant support provided by the previous high water table; ground subsides, resulting in wet areas and tilted trees; and collapse occurs, creating sinkholes.

\section{Hazards and Hazard Prediction}

The karst-associated hazards in this area are: (1) unpredictable collapse during forest operations (Fig. 4); (2) threats to infrastructure such as the railway, the electricity transmission line, roads and the Dulverton Tip (Fig. 1); (3) changes to biodiversity of streams resulting from intermittent flows and drying of channels downstream of streamsinks; and (4) changed water chemistry. The study demonstrates that the risks associated with water-table lowering by quarrying in limestone are not limited to classical "cones of depression" immediately around quarries and mines. Effects are magnified if relict subsurface stream channels (cave systems) are intersected by mining, as predicted in this area by Jennings 
(1959), and may extend for kilometres, as shown in this study and elsewhere (Langer, 2001). Predicting the presence and orientation of such cave systems is difficult, but they are likely to occur preferentially along features such as fault lines, fracture zones, or as in the case studied, syncline axes. As emphasised by Parise (2016), karst features and their associated water resources are vulnerable and quarrying in karst areas should be carefully designed, planned and controlled. In this karst area, the actual environmental effects and potential negative socio-economic effects of mining on infrastructure and rural land use are large and need to be addressed.

\section{Acknowledgements}

Forico Pty Limited allowed access to the study area. We are indebted to James Dick and Simon Cook of Forico Pty Ltd for encouraging the research and acquiring and providing the high-resolution drone imagery used for sinkhole mapping. The Forest Practices Authority Board provided the funding for B. Burke to undertake this project, and travel costs for $\mathrm{H}$. Hofmann. The analysis of the activated charcoal samples was undertaken at Ozark Underground Laboratory, Missouri, USA. We are grateful to Martin Peersmann of the Ministerie van Infrastrutuur en Milieu, Den Haag and two anonymous reviewers for their constructive suggestions for improving the manuscript.

\section{References}

Al-Halbouni, D., Holohan, E.P., Taheri, A., Schöpfer, M.P.J., Emam, S., and Dahm, T., 2018, Geomechanical modelling of sinkhole development using distinct elements: model verification for a single void space and application to the Dead Sea area: Solid Earth, v. 9, p.1341-1373. https:// doi.org/10.5194/se-9-1341-2018

Augarde, C.E., Lyamin, A.V., and Sloan, S.W., 2003. Prediction of undrained sinkhole collapse: Journal of Geotechnical and Geoenvironmental Engineering, v. 129, p. 197-205. https://doi.org/10.1061/(ASCE)1090-0241(2003)129:3(197)

Basso, A. Bruno, E., Parise, M., and Pepe, M., 2013, Morphometric analysis of sinkholes in a karst coastal area of southern Apulia, Italy: Environmental Earth Sciences, v. 70, p. 2545-2559. https://doi.org/10.1007/s12665-013-2297-z

Baublys, K.A., Hamilton, S.K., Golding, S.D., Vink, S., and Esterle, J., 2015, Microbial controls on the origin and evolution of coal seam gases and production waters of the Walloon Subgroup; Surat Basin, Australia: International Journal of Coal Geology, v. 147-148, p. 85-104. https:// doi.org/10.1016/j.coal.2015.06.007

Bonacci, O., 2004, Hazards caused by natural and anthropogenic changes of catchment area in karst: Natural Hazards and Earth System Sciences, v. 4, p. 655-661. https://doi.org/10.5194/nhess-4-655-2004

Brinkmann, R., Parise, M., Dye, D., 2008, Sinkhole distribution in a rapidly developing urban environment: Hillsborough County, Tampa Bay area, Florida: Engineering Geology, v. 99, p. 169-184. https://doi.org/10.1016/j.enggeo.2007.11.020

Brown, A.V., McClenaghan, M.P., Turner, N., Baillie, P.W., Lennox, P.G., McClenaghan, J., Lennox, P., and Williams, P.R., 1982, Geological Atlas 1:50000 series. Huntley. Tasmanian Department of Mines.

Bureau of Meteorology, 2019, Monthly Rainfall, Railton (Dowbiggin Street) station 91332. http://www.bom.gov.au/jsp/ncc/cdio/weatherData/ av?p_nccObsCode=139\&p_display_type=dataFile\&p_stn_num=091332 .

Burke, B., 2018, An investigation into sinkhole formation in Railton, Tasmania [B.Sc. Thesis]: Queensland, University of Queensland.

Calligaris, C., Devoto, S., and Zini L., 2017, Evaporite sinkholes of the Friuli Venezia Giulia region (NE Italy): Journal of Maps, v. 13 , p. $406-414$. https://doi.org/10.1080/17445647.2017.1316321

Compston, W., McDougall, I., and Heier, K.S., 1968, Geochemical comparison of the Mesozoic basaltic rocks of Antarctica, South Africa, South America and Tasmania: Geochimica et Cosmochimica Acta 32, p. 129-149. https://doi.org/10.1016/S0016-7037(68)80001-8

Cooley, T., 2002, Geological and geotechnical context of cover collapse and subsidence in mid-continent US clay-mantled karst: Environmental Geology, v. 42, p. 469-475. https://doi.org/10.1007/s00254-001-0507-6

Cooper, A.H., Farrant, A.R., and Price, S.J., 2011, The use of karst geomorphology for planning, hazard avoidance and development in Great Britain: Geomorphology, v. 134, p. 118-131. https://doi.org/10.1016/j.geomorph.2011.06.004

Csaky, D., 2003, Review of karst hazards in the Wanneroo area, Perth, Western Australia. Minerals and Geohazards Division, Perth Cities Project. Geoscience Australia report, $44 \mathrm{p}$.

Dell'Aringa, M., Giannecchini, R., and Puccinelli, A., 2014, Small sinkhole-like features in alluvial plains: the example of Paganico (Lucca Plain, Italy). Natural Hazards and Earth Systems Sciences, v. 1, p. 3413-3448. https://doi.org/10.5194/nhessd-1-3413-2013

Delle Rose, M., Parise M., and Andriani, G.F., 2007, Evaluating the impact of quarrying on karst aquifers of Salento (southern Italy), in Parise, M., and Gunn, J., eds.: Natural and anthropogenic hazards in karst areas: Recognition, Analysis and Mitigation. Geological Society of London, Special Publication 279, p. 153-171. https://doi.org/10.1144/SP279.13

Doctor, D.H., and Young, J.A., 2013, An Evaluation of Automated GIS Tools for Delineating Karst Sinkholes and Closed Depressions from 1-Meter LiDAR-Derived Digital Elevation Data: https://scholarcommons.usf.edu/cgi/viewcontent.cgi?referer=http://scholar.google.com. au/\&httpsredir=1\&article=1156\&context=sinkhole_2013. https://doi.org/10.5038/9780979542275.1156

Donaldson, R.C., 1984, An inspection of sinkholes at Railton: Tasmania Department of Mines 1984/88.

Eberhard, R., 1994, Inventory and management of the Junee River karst system, Tasmania: Forestry Tasmania, Hobart, 125 p.

Eberhard, R., 1998, Planning for karst management in multiple-use forest: The Junee-Florentine karst study: Tasforests, v. 10, p. 33-47.

Eberhard, R., 2007, Land Classification and Tasmania's Karst Estate - A GIS Review, AKMA Journal, v. 66, p.10-14.

Feuerstein, D. L., and Selleck, R. E., 1963, Fluorescent tracers for dispersion measurement: Journal of the Sanitary Engineering Division, v. 89, p. 1-22.

Filippini, M., Squarzoni, G., De Waele, J., Fiorucci, A., Vigna, B., Grillo, B., Riva, A., Rossetti, S., Zini, L., Casagrande, G., and Stumpp, C., 2018, Differentiated spring behavior under changing hydrological conditions in an alpine karst aquifer: Journal of Hydrology, v. 556, p. 572-584. https://doi.org/10.1016/j.jhydrol.2017.11.040

Flett, V., Maurice, L., Finlayson, A., Black, A.R., MacDonald, A.M., Everest, J., and Kirkbride, M.P., 2017, Meltwater flow through a rapidly deglaciating glacier and foreland catchment system: Virkisjökull, SE Iceland: Hydrology Research, v. 48, p. 1666-1681. https://doi.org/10.2166/ nh.2017.205

Forest Practices Authority, 1987, Forest Practices Code: Forest Practices Authority, Hobart. 
Forest Practices Authority, 2015, Forest Practices Code: Forest Practices Authority, Hobart.

Frisbee, M.D., Meyers, Z.P., Miller, J.B., Gleason, C.L., Stewart-Maddox, N.S., Larson, E.B., Granger, D.E., Saksena, S., Dey, S., and Frisbee, E.E., 2019, Processes leading to the re-activation of a sinkhole in buried karst and the subsequent drying of waterfalls in a small catchment located in northern Indiana, USA: Journal of Cave and Karst Studies, v. 81, p. 69-83. https://doi.org/10.4311/2017ES0116

GNIP, 2018, Global Network of Isotopes in Precipitation, Water Resources Program, International Atomic Energy Agency, Vienna. http://wwwnaweb.iaea.org/napc/ih/lHS_resources_gnip.html.

Goldscheider, N., and Neukum, C., 2010, Fold and fault control on the drainage pattern of a double-karst-aquifer system, Winterstaude, Austrian Alps: Acta Carsologica, v. 39, p. 173-186. https://doi.org/10.3986/ac.v39i2.91

Goldscheider, N., Meiman, J., Pronk, M., and Smart, C., 2008, Tracer tests in karst hydrogeology and speleology: International Journal of Speleology, v. 3791, p. 27-40. https://doi.org/10.5038/1827-806X.37.1.3

Grimes, K.G., 1994, The south-east karst province of South Australia: Environmental Geology, v. 23, p. 134-148. https://doi.org/10.1007/ BF00766987

Grimes, K.G., 1999, The water below: an introduction to karst hydrology and the hydrological setting of the Australian karsts: Proceedings of the $13^{\text {th }}$ Australasian Conference on Cave and Karst Management, p. 24-31.

Gutiérrez-Santolalla, F., Gutiérrez-Elorza, M., Marín, C., Desir, G., and Maldonado, C., 2005, Spatial distribution, morphometry and activity of La Puebla de Alfindén sinkhole field in the Ebro river valley (NE Spain): applied aspects for hazard zonation: Environmental Geology, v. 48, p. 360-369. https://doi.org/10.1007/s00254-005-1280-8

Gutiérrez, F., Parise, M., De Waele, J., and Jourde, H., 2014, A review on natural and human-induced geohazards and impacts in karst: Earth Science Reviews, v. 138, p. 61-88. https://doi.org/10.1016/j.earscirev.2014.08.002

Heidari, M., Khanlari, G.R., Taleb Beydokhti, A.R., and Momeni, A.A., 2011, The formation of cover collapse sinkholes in North of Hamedan, Iran: Geomorphology, v. 132, p. 76-86. https://doi.org/10.1016/j.geomorph.2011.04.025

Hergt, J.M., Chappell, B.W., McCulloch, M.T., McDougall, I., and Chivas, A.R., 1989, Geochemical and isotopic constraints on the origin of the Jurassic dolerites of Tasmania: Journal of Petrology, v. 30, p. 841-883. https://doi.org/10.1093/petrology/30.4.841

Hobbs S. L., and Gunn, J., 1998, The hydrogeological effect of quarrying karstified limestone: options for prediction and mitigation: Quarterly Journal of Engineering Geology and Hydrogeology, v. 31, p. 147-157. https://doi.org/10.1144/GSL.QJEG.1998.031.P2.10

Hunt, B.B., Smith, B.A., Adams, M.T., Heirs, S.E., and Brown N., 2013, Cover-collapse sinkhole development in the Cretaceous Edwards limestone, Central Texas: NCKRI Symposium 2, $13^{\text {th }}$ sinkhole conference, p. 89-101. https://doi.org/10.5038/9780979542275.1117

Hyatt, J.A., and Jacobs, P.M., 1996, Distribution and morphology of sinkholes triggered by flooding following Tropical Storm Alberto at Albany, Georgia, USA: Geomorphology, v. 17, p. 305-316. https://doi.org/10.1016/0169-555X(96)00014-1

Intrieri, E., Fontanelli, K., Bardi, F., Marini, F., Carlà, T., Pazzi, V., Di Filippo, M., and Fanti, R., 2018, Definition of sinkhole triggers and susceptibility based on hydrogeomorphological analyses: Environmental Earth Sciences, v. 77, p. 4. https://doi.org/10.1007/s12665-017-7179-3

Jennings, I.B., 1959, Geology and site investigations in the vicinity of the Goliath Portland cement Company's works, Railton, Tasmania. Part 2: Mineral Resources Tasmania Report UR1960_046_61.

Jennings, I.B., 1960, Geology and site investigations in the vicinity of the Goliath Portland cement Company's works - Railton, Tasmania: Mineral Resources Tasmania Report TR4_62_90.

Jennings, I.B., 1961, Geological sequence in recent drilling near the Goliath Cement company's works - Railton. Mineral Resources Tasmania Report TR5_114_117.

Jia, L., Lujuan, L., Meng, Y., Wu, Y., Pan, Z., and Yin, R., 2018, Responses of cover-collapse sinkholes to groundwater changes: a case study of early warning of soil cave and sinkhole activity on Datansha Island in Guangzhou, China: Environmental Earth Sciences, v. 77 , p. 488. https:// doi.org/10.1007/s12665-018-7603-3

Jones, R., Cosgrove, R., Allen, J., Cane, S., Kiernan, K., Webb, S., Loy, T., West, D., and Stadler, E., 1988, An archaeological reconnaissance of karst caves within the southern forests region of Tasmania, September 1987: Australian Archaeology, v. 26, p. 1-23.

Jovanelly, T.J., 2014, Sinkholes and a disappearing lake: Victory Lake case study: Journal of Cave and Karst Studies: v. 76, p. 217-229. https:// doi.org/10.4311/2012ES0272

Kaufmann, O., and Quinif, Y., 2002, Geohazard map of cover-collapse sinkholes in the 'Tournaisis' area, southern Belgium: Engineering Geology, v. 65, p. 117-124. https://doi.org/10.1016/S0013-7952(01)00118-1

Kaufmann, G., and Romanov, D., 2016, Structure and evolution of collapse sinkholes: combined interpretation from physico-chemical modelling and geophysical field work: Journal of Hydrology, v. 540, p. 688-698. https://doi.org/10.1016/j.jhydrol.2016.06.050

Khanlari, G., Heidari, M., Momeni, A.A., Ahmadi, M., and Beydokhti, A.T., 2012, The effect of groundwater overexploitation on land subsidence and sinkhole occurrences, western Iran: Quarterly Journal of Engineering Geology and Hydrogeology, v. 45, p. 447-456. https://doi. org/10.1144/qjegh2010-069

Kiernan, K., 1989, Karst, Caves and Management at Mole Creek, Tasmania. A report to the Forestry Commission and National Parks \& Wildlife Service, Tasmania 1984: Department of Parks, Wildlife and Heritage Occasional Paper no.22. Forestry Commission, Hobart, 140 p.

Kiernan, K., 1990, Underground drainage at Mole Creek, Tasmania: Australian Geographical Studies, v. 28, p. 224-239. https://doi. org/10.1111/j.1467-8470.1990.tb00614.x

Kiernan, K., 1993, The Exit Cave Quarry: Tracing waterflows and resource policy evaluation. Helictite, v. 31, p.27-42.

Kiernan, K., 1995a, Karst management in commercial forests, in Spate, A.P., Bell. P., and Henderson, K. eds: Cave Management in Australasia: v. 7, p. 37-40.

Kiernan. K., 1995b, An atlas of Tasmanian Karst v. 1-2: Research Report No.10, Tasmanian Forest Research Council, Inc. Hobart, Tasmania.

Kiernan, K., Eberhard, R., and Shannon, C.H.C., 1994, Further hydrogeological investigations of the Mill Creek-Kansas Creek area, Northern Tasmania: Tasforests, v. 6, p. 7-22.

Kiernan, K. 2002, Sinkhole Manual: Forest Practices Authority, Hobart.

Knöll, P., and Scheytt, T., 2018, A tracer test to determine a hydraulic connection between the Lauchert and Danube karst catchments (Swabian Alb, Germany): Hydrogeology Journal, v. 26, p. 429-437. https://doi.org/10.1007/s10040-017-1678-x

Kobal, M., Bertoncelj, I., Pirotti, F., Dakskobler, I., and Kutnar, L., 2015, Using lidar data to analyse sinkhole characteristics relevant for understory vegetation under forest cover-Case study of a high karst area in the Dinaric Mountains: PLOS ONE 10(3): e0122070. https://doi. org/10.1371/journal.pone.0122070

LaMoreaux, P.E., Powell, W.J., and LeGrand, H.E., 1997, Environmental and legal aspects of karst areas: Environmental Geology, v. 29, p. 23-26. https://doi.org/10.1007/s002540050100 
Langer, W.H., 2001, Potential environmental impacts of quarrying stone in karst: a literature review: US Department of the Interior, US Geological Survey, Open-File Report OF-01-0484. https://doi.org/10.3133/ofr01484

Lauber, U., Ufrecht, W., and Goldscheider, N., 2014, Spatially resolved information on karst conduit flow from in-cave dye tracing: Hydrology and Earth System Sciences, v. 18, p. 435-445. https://doi.org/10.5194/hess-18-435-2014

Lipar, M., Stepišnik, U., and Ferk, M., 2019, Multiphase breakdown sequence of collapse doline morphogenesis: an example from Quaternary aeolianites in Western Australia: Geomorphology v. 327, p. 572-584. https://doi.org/10.1016/j.geomorph.2018.11.031

Liu, J., Fu, G., Song, X., Charles, S.P., Zhang, Y., Han, D., and Wang, S., 2010, Stable isotope compositions in Australian precipitation: Journal of Geophysical Research, v. 115, D23, https://doi.org/10.1029/2010JD014403

Lolcama, J.I., Cohen, H.A., and Tonkin, M.J., 2002, Deep karst conduits, flooding, and sinkholes: lessons for the aggregates industry: Engineering Geology, v. 65, p. 151-157. https://doi.org/10.1016/S0013-7952(01)00122-3

Marcus, W.A., Roberts, K., Harvey, L., and Tackman, G., 1992, An evaluation of methods for estimating Manning's $n$ in small mountain streams: Mountain Research and Development, v. 12, p. 227-239. https://doi.org/10.2307/3673667

Martinotti, M.E., Pisano, L., Marchesini, I., Rossi, M., Peruccacci, S., Brunetti, M.T., Melillo, M., Amoruso, G., Loiacono, P., Vennari, C., Vessia, G., Trabace, M., Parise, M., and Guzzetti, F., 2017, Landslides, floods and sinkholes in a karst environment: the 1-6 September 2014 Gargano event, southern Italy: Natural Hazards and Earth System Sciences, v. 17, p. 467-480. https://doi.org/10.5194/nhess-17-467-2017

Matthews. W.L., Hudspeth. J.W., and Donaldson, R.C., 1983, Sinkholes at Railton railway station: Tasmania Department of Mines, v. 39 , p. 1-6. McClenaghan, M.P., 2003, Railton Sheet 4442, Digital Geological Atlas 1: 25000 series: Mineral Resources Tasmania' Hobart.

McIntosh, P.D., Eberhard, R., Slee, A., Moss P., Price D.M., Donaldson P., Doyle R., and Martins J., 2012, Late Quaternary extraglacial cold-climate deposits in low and mid-altitude Tasmania and their climatic implications: Geomorphology, v. 179, p. 21-39. https://doi.org/10.1016/j. geomorph.2012.08.009

Miles, K.E., Hubbard, B., Quincey, D.J., Miles, E.S., Irvine-Fynn, T.D.L., and Rowan, A.V., 2019, Surface and subsurface hydrology of debris-covered Khumbu Glacier, Nepal, revealed by dye tracing, Earth and Planetary Science Letters: v. 513, p. 176-186. https://doi.org/10.1016/j. epsl.2019.02.020

North, L.A., van Beynen, P.E., Parise, M., 2009, Interregional comparison of karst disturbance: West-central Florida and southeast Italy: Journal of Environmental Management, v. 90, p. 1770-1781. https://doi.org/10.1016/j.jenvman.2008.11.018

Noury, G., Perrin, J., Li-Hua Luu, L-H., Philippe, P., and Gourdier. S., 2018, Role of floods on sinkholes occurrence in covered karst terrains: case study of Orléans area (France) during the 2016 meteorological event and perspectives for other karst environments:15th Multidisciplinary Conference on Sinkholes and the Engineering and Environmental Impacts of Karst, April 2018, Shepherdstown, W.Va. https://doi. org/10.5038/9780991000982.1014

O'Driscoll, M.A., and DeWalle, D.R., 2006, Stream-air temperature relations to classify stream-ground water interactions in a karst setting, central Pennsylvania, USA: Journal of Hydrology, v. 329, p. 140-153. https://doi.org/10.1016/j.jhydrol.2006.02.010

Osborne, R.A.L., 1994, Caves, cement, bats, and tourists: karst science and limestone resource management in Australia, Journal and Proceedings, Royal Society of New South Wales, v. 127, p. 1-22.

Pan, Z., Jiang, X., Lei, M., Guan, Z., Wu, Y., and Gao, Y., 2018, Mechanism of sinkhole formation during groundwater-level recovery in karst mining area, Dachengqiao, Hunan province, China: Environmental Earth Sciences: v. 77, p. 799. https://doi.org/10.1007/s12665-018-7987-0

Parise, M., 2015, Karst geo-hazards: causal factors and management issues: Acta Carsologica, v. 44, p. 401-414. https://doi.org/10.3986/ ac.v44i3.1891

Parise, M., 2016, Modern resource use and its impact in karst areas - mining and quarrying: Zeitschrift für Geomorphologie, v. 60 (Suppl. 2), p, 199-216. https://doi.org/10.1127/zfg_suppl/2016/00312

Parise, M., and Pascali, V., 2003, Surface and subsurface environmental degradation in the karst of Apulia (southern Italy): Environmental Geology, v. 44, 247-256. https://doi.org/10.1007/s00254-003-0773-6

Parise, M., Pisano, L., and Vennari, C., 2018, Sinkhole clusters after heavy rainstorms: Journal of Cave and Karst Studies, v. 80, p.28-38. https:// doi.org/10.4311/2017ES0105

Pepe, M., and Parise, M., 2014, Structural control on development of karst landscape in the Salento Peninsula (Apulia, SE Italy): Acta Carsologica, v. 43, p. 101-114. https://doi.org/10.3986/ac.v43i1.643

Polk, J.S., North, L.A., Federico, R., Ham, B., Nedvidek, D., McClanahan, K., Kambesis, P., and Marasa, M.J., 2015, Cars and Karst: Investigating the National Corvette Museum Sinkhole, NCKRI Symposium 5, 14th sinkhole conference, p. 477-481. https://doi. org/10.5038/9780991000951.1079

Poulain, A., Watlet, A., Kaufmann, O., Van Camp, M., Joude, H., Mazzilli, N., Rochez, G., Deleu, R., Quinif, Y., and Hallet, V., 2018, Assessment of groundwater recharge processes through karst vadose zone by cave percolation monitoring: Hydrological Processes, v. 32, p. 2069-2083. https://doi.org/10.1002/hyp.13138

Ray, G.A., and Megahan, W.F., 1979, Measuring cross sections using a sag tape: a generalized procedure: General Technical Report INT-GTR47. Ogden, UT: US Department of Agriculture, Forest Service, Intermountain Forest and Range Experiment Station, v. 12 , p. 47.

Scanlon, B.R., Healy, R.W., and Cook, P.G., 2002, Choosing appropriate techniques for quantifying groundwater recharge: Hydrogeology Journal, v. 10, p. 18-39. https://doi.org/10.1007/s10040-001-0176-2

Sharples, C., 2002, Karst survey: Settlement block, Florentine valley (explanatory notes and data dictionary): Report for Norske Skog, New Norfolk, Tasmania.

Sharples, C., 2018, A dye tracing experiment at the Settlement: looking for a minor master cave in the Florentine Valley: Speleo Spiel (Journal of the Southern Tasmanian Caverneers), v. 425, p.12-14.

Siska, P.P., Goovaerts, P., and Hung, I.K., 2016, Evaluating susceptibility of karst dolines (sinkholes) for collapse in Sango, Tennessee, USA: Progress in Physical Geography, v. 40, p. 579-597. https://doi.org/10.1177/0309133316638816

Slee, A., McIntosh, P., Webb, J., Sharples, C., and Williams, K., 2019, Managing geomorphic values within Tasmanian plantations on karst terrain: Australian Forestry, v. 82, p. 127-138. https://doi.org/10.1080/00049158.2019.1656704

Soliman, M.H., Perez, A.L., Nam, B.H., and Ye, M., 2018, Physical and numerical analysis on the mechanical behaviour of cover-collapse sinkholes in central Florida: 15th sinkhole conference NCKRI Symposium, v. 7, 405-415. https://doi.org/10.5038/9780991000982.1040

Tharp, T. M., 1999, Mechanics of upward propagation of cover-collapse sinkholes: Engineering Geology, v. 52, p. 23-33. https://doi.org/10.1016/ S0013-7952(98)00051-9

Urich, P. B., 2002, Land use in karst terrain: review of impacts of primary activities on temperate karst ecosystems: Department of Conservation Wellington. 
van Beynen, P.E., and Townsend, K.M., 2005, A disturbance index for karst environments: Environmental Management, v. 36, p. 101-116. https:// doi.org/10.1007/s00267-004-0265-9

Vigna, B., and Banzato, C., 2015, The hydrogeology of high-mountain carbonate areas: an example of some Alpine systems in southern Piedmont (Italy): Environmental Earth Sciences, v. 74, p. 267-280. https://doi.org/10.1007/s12665-015-4308-8

Waltham, T., 2008, Sinkhole hazard case histories in karst terrains: Quarterly Journal of Engineering Geology and Hydrogeology, v. 41, p. 291-300. https://doi.org/10.1144/1470-9236/07-211

Water Management Act 1999. https://www.legislation.tas.gov.au/view/whole/htmL/inforce/current/act-1999-045 [accessed July 2, 2019$].$

Yan, C., Luo, G., Wang, Y., Chen, M., Zhan, Q., Wan, G., Chen, X., Zheng, G., and Guo, J., 2008, Compressive structural control on karst development, in Yuhr, L.B., Alexander, E.C., and Beck, B.F., eds: Sinkholes and the Engineering and Environmental Impacts of Karst, p. 54-61. https://doi.org/10.1061/41003(327)6

Zhou, W., and Beck, B.F., 2008, Management and mitigation of sinkholes on karst lands: an overview of practical applications: Environmental Geology, v. 55, p. 837-851. https://doi.org/10.1007/s00254-007-1035-9

Zhou, W., and Lei, M., 2018, Summary editorial for karst hydrogeology: advances in karst collapse studies: Environmental Earth Sciences, v. 77, p. 803. https://doi.org/10.1007/s12665-018-7990-5 